\title{
Non-Coding RNAs in Multiple Myeloma Bone Disease Pathophysiology
}

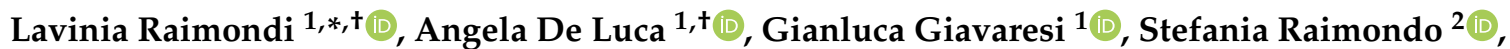 \\ Alessia Gallo ${ }^{3}$, Elisa Taiana 4,5®0, Riccardo Alessandro 2,6® ${ }^{\circledR}$, Marco Rossi ${ }^{7}$, Antonino Neri ${ }^{4,5}$, \\ Giuseppe Viglietto ${ }^{7}$ and Nicola Amodio ${ }^{7, *}$ \\ 1 IRCSS Istituto Ortopedico Rizzoli, SC Scienze e Tecnologie Chirurgiche-SS Piattaforma Scienze Omiche per \\ Ortopedia Personalizzata, 40136 Bologna, Italy; angela.deluca@ior.it (A.D.L.); gianluca.giavaresi@ior.it (G.G.) \\ 2 Department of Biomedicine, Neurosciences and Advanced Diagnostics (Bi.N.D), Section of Biology and \\ Genetics, University of Palermo, 90133 Palermo, Italy; stefania.raimondo@unipa.it (S.R.); \\ riccardo.alessandro@unipa.it (R.A.) \\ 3 IRCCS ISMETT (Istituto Mediterraneo per i Trapianti e Terapie ad alta specializzazione), \\ Research Department, 90127 Palermo, Italy; agallo@ismett.edu \\ 4 Department of Oncology and Hemato-oncology, University of Milan, 20122 Milan, Italy; \\ elisa.taiana@unimi.it (E.T.); antonino.neri@unimi.it (A.N.) \\ 5 Hematology, Fondazione Cà Granda IRCCS Policlinico, 20122 Milan, Italy \\ 6 Institute for Biomedical Research and Innovation (IRIB), National Research Council (CNR), \\ 90146 Palermo, Italy \\ 7 Department of Experimental and Clinical Medicine, Magna Graecia University of Catanzaro, \\ 88100 Catanzaro, Italy; rossim@unicz.it (M.R.); viglietto@unicz.it (G.V.) \\ * Correspondence: lavinia.raimondi@ior.it (L.R.); amodio@unicz.it (N.A.); \\ Tel.: +39-091-6236011 (L.R.); +39-0961-3694159 (N.A.) \\ + These authors equally contributed to this work.
}

Received: 10 August 2020; Accepted: 8 September 2020; Published: 9 September 2020 updates

\begin{abstract}
Bone remodeling is uncoupled in the multiple myeloma (MM) bone marrow niche, resulting in enhanced osteoclastogenesis responsible of MM-related bone disease (MMBD). Several studies have disclosed the mechanisms underlying increased osteoclast formation and activity triggered by the various cellular components of the MM bone marrow microenvironment, leading to the identification of novel targets for therapeutic intervention. In this regard, recent attention has been given to non-coding RNA (ncRNA) molecules, that finely tune gene expression programs involved in bone homeostasis both in physiological and pathological settings. In this review, we will analyze major signaling pathways involved in MMBD pathophysiology, and report emerging evidence of their regulation by different classes of ncRNAs.
\end{abstract}

Keywords: bone disease; long non-coding RNA; miRNA; multiple myeloma; non-coding RNA; tumor microenvironment

\section{Introduction}

Multiple myeloma bone disease (MMBD) is a hallmark feature of multiple myeloma (MM), the second most common hematological malignancy characterized by abnormal proliferation of monoclonal plasma cells (PCs) in the bone marrow (BM). MMBD strikes approximately $80 \%$ of MM patients and causes debilitating bone pain, pathologic fractures, vertebral collapse and hypercalcemia, inducing significant patients' morbidity and mortality [1].

The bone marrow microenvironment (BMM) is composed by a mineralized extracellular matrix and cellular components, including osteoclasts (OCs), osteoblasts (OBs), osteocytes (OCYs), immune 
cells, endothelial cells and stromal cells. Bone remodeling under pathological conditions is characterized by a strong inhibition of OBs activity, which leads to bone loss as OBs are unable to repair the lesions caused by the excessive osteoclastic resorption; the latter process is strongly supported by MM cells, which can exacerbate OCs activity promoting their maturation directly or by physically interacting with other cellular components, such as the BM stromal cells (BMSCs). In turn, cell-cell interactions and soluble factors or matrix-associated growth factors released from the resorbed bone increase MM cell proliferation and prompt tumor progression [2-4].

To effectively trigger $\mathrm{BD}$, cellular components of the BMM produce and/or secrete a number of functional molecules, which collectively contribute to the osteoclastogenic events. In this regard, non-coding RNAs (ncRNAs) have recently emerged as fine regulators of gene expression programs underlying key molecular events featuring bone remodeling in MM.

Herein, we will briefly discuss the signaling pathways implicated in the development of MMBD, and, will then, analyze how they are modulated by manipulation or release of ncRNAs from different BMM cells.

\section{Pathophysiology of MMBD}

A great deal of literature has revealed that MMBD is regulated by a multiplicity of signaling pathways associated with anti-osteogenic, pro-osteoclastic and tumor-supporting properties [5]. Several intracellular and intercellular signaling cascades, as well as a large number of cytokines and chemokines, have been deeply studied and are nowadays considered valuable therapeutic targets in MMBD [6]. Dysregulation of signaling pathways by defective expression and/or function of ncRNAs has been implicated in MM pathogenesis, with an emerging role, also, in the onset of MMBD [7]. In this section, we will discuss about the main molecules and signaling pathways underlying MMBD pathophysiology; subsequently, available information about different ncRNAs known to affect relevant MMBD-related molecules and/or potentially involved in MMBD pathogenetic mechanisms will be provided.

\subsection{RANK/RANKL/OPG Pathway}

A key pathway regulating osteoclastogenesis is the RANK/RANKL/OPG signaling cascade. RANKL is expressed by BMSCs and OBs, while its receptor, the type I transmembrane protein RANK, is expressed by OCs precursor cells and mature OCs. RANKL/RANK interaction activates a complex signaling cascade, characterized by induction of the nuclear factor of activated T-cells, cytoplasmic 1 (NFATc1), which in turn regulates OC-specific genes, namely the tartrate-resistant acid phosphatase (TRAP), osteoclast-associated receptor (OSCAR) and cathepsin K (CTSK). Conversely, OPG is a soluble decoy receptor for RANKL. In physiologic conditions, a balanced RANKL/OPG ratio enables a correct bone remodeling, while in MM this ratio is strongly unbalanced, thus fostering bone destruction. MM PCs induce RANKL upregulation in OBs and BMSCs within the BMM; moreover, MM cells can express and secrete themselves RANKL [8]. Several studies evidenced RANKL upregulation in $\mathrm{BM}$ biopsies of MM patients and a positive correlation between the number of osteolytic lesions and increasing levels of serum RANKL $[6,9,10]$.

\subsection{Notch Pathway}

Notch pathway includes four transmembrane receptors (Notch1-4) and five ligands (Jagged 1,2 and Delta-like 1,3,4). Following the receptor-ligand interaction, two proteolytic cleavages are mediated by ADAM/TACE and $\gamma$-secretase complex, which release the intracellular portion of Notch (ICN) to the nucleus where activates its target genes Hes and Hey. Notch pathway components are aberrantly expressed in MM cells and implicated in osteoclastogenesis and osteoblastogenesis processes occurring in the BMM; in particular, the roles played by Notch1, -2 and -3 , as well as by Jagged 1 and -2 , have been described, indicating that not all signaling components are simultaneously involved in the same process or may even have opposing biological effects [11-13] Within the tumor microenvironment, 
the Notch/Ligand interactions can be homotypical or heterotypical. Notch signaling interferes with the maturation of the early OB pool by inhibiting the $W n t / \beta$-catenin pathway in pre-OBs [14]. BMSCs also express Notch receptors that may be triggered by Jagged ligands of MM cells and subsequently increase RANKL production $[1,15,16]$.

Osteoclastogenesis can be differently regulated by Notch signaling according to the various ligands and the receptor isoforms involved. For instance, Notch1 and Notch3 have been described as suppressors of OC differentiation [17], while Notch2 is upregulated during RANKL-induced early OC differentiation and involved in the late stage of osteoclastogenesis [18-20].

\subsection{Wingless and Integration-1 (Wnt) Pathway}

Wingless and integration-1 (Wnt) signaling is a master regulator of bone homeostasis, as it closely regulates the fine balance between bone-forming OBs and bone-resorbing OCs [21]. In the absence of Wnt, cytoplasmic $\beta$-catenin is bound and phosphorylated by a cytosolic complex constituted by the scaffold proteins APC, Axin1, the kinases GSK3 and CK1. Phosphorylation of $\beta$-catenin marks it for ubiquitination and proteasomal degradation [22]. The binding of Wnt with their cognate ligands, the Fz and LRP5/6 coreceptors, activates the signaling downstream; the receptor complex recruits the effector protein disheveled (Dvl), which in turn recruits Axin1-GSK3, thus blocking the cytosolic destruction complex. Hence, stable $\beta$-catenin translocates to the nucleus where, together with specific transcription cofactors, can activate the expression of Wnt target genes [23,24]. Regarding bone metabolism, Wnt signaling directs MSC differentiation towards differentiation into OBs [25]; furthermore, Wnt signaling promotes OBs survival, partly through the Src/ERK and PI3K/Akt pathways [21,26].

MM cells inhibit Wnt signaling and promote an OBs/OCs unbalance. MM cells and osteocytes express Wnt antagonists such as sclerostin, Dickkopf-1 (Dkk-1) and soluble frizzled-related proteins (sFRP-2/3), whose activity leads to OB suppression [27,28].

\subsection{Dickkopf-1 (Dkk-1)}

Wnt pathway can be also antagonized by Dkk-1, which plays an important role in osteoblastogenesis and skeletal development $[27,29,30]$. The binding of Dkk-1 to LRP5/6 receptors, in combination with the Kremen1/2 transmembrane proteins, induces the internalization of LRP and interferes with the activation of the canonical Wnt/ $\beta$-catenin pathway [31]. Consequently, osteoblastogenesis and formation of the mineralized matrix are inhibited and, in turn, the undifferentiated BMSCs secrete IL- 6 sustaining the proliferation of MM cells secreting Dkk-1 [32]. Dkk-1 also promotes osteoclastogenesis and bone resorption by modulating RANKL and OPG expression in OBs [33].

\subsection{Sclerostin}

Sclerostin (SOST), a cysteine knot-containing protein mainly produced by osteocytes, induces OB apoptosis by the caspase pathway and antagonizes the Wnt pathway by binding to the extracellular domain of LRP5/6 transmembrane receptors on osteoblast-lineage cells; moreover, sclerostin may prevent type I and type II bone morphogenetic proteins (BMPs) from binding to their receptors, thus reducing the BMP-mediated mineralization in OBs [34,35]. Sclerostin stimulates osteoclastogenesis also by increasing RANKL/OPG ratio [36], and its serum levels correlate with advanced MMBD and poor patient survival [37].

\subsection{Bruton's Tyrosine Kinase (BTK)}

Another important pathway promoting osteoclastogenesis is downstream the Bruton's tyrosine kinase (BTK), a non-receptor tyrosine kinase member of the Tec family also upregulated in MM PCs $[38,39]$. BTK inhibition reduced both tumor burden and osteolytic BD by decreasing OC number and activity, the adhesion of MM cells to BMSCs and the levels of BMSC-secreted growth factors [40]. Runt-related transcription factor 2 (Runx2), is critical in osteoblastogenesis and bone formation [41,42], 
and its upregulation correlated with an aggressive phenotype and poor prognosis of MM [43]. In MMBD, human MM cells inhibit OB formation and differentiation blocking the expression of Runx2/CBFA1.

\subsection{Cytokines}

MM is typically characterized by a desynchronized cytokine system with increased levels of pro-inflammatory cytokines [44]. A gene expression inflammatory signature could predict MM progression and patient survival and recently it has been identified an 8-genes signature (IL8, IL10, IL17A, CCL3, CCL5, VEGFA, EBI3 and NOS2) which accurately differentiates monoclonal gammopathy of undetermined significance (MGUS), smoldering myeloma (sMM) and MM [45]. MM cells can induce OCs differentiation and osteolytic activity, by modulating release from OBs of the proinflammatory cytokine IL-6 inside the tumor microenvironment; in turn, IL-6 inhibits OBs activity and induces the production of RANKL. Importantly, MM cells can induce BM adipocytes to make a more supportive niche and to increase OC activity through IL-6 and other molecules [46]. High levels of IL-8 are secreted from BMSCs of MM patients [47], which stimulated OC formation in vitro [48]. Macrophage inflammatory protein-1alpha (MIP-1 $\alpha$ ) is a cytokine with bone-resorbing properties secreted by MM cells and also by other BMM cells [49]; high expression of MIP- $1 \alpha$ was found in BM PCs and in the serum of MM patients, and positively correlated with the presence of extensive lytic lesions and increased angiogenesis [50]. In addition, the inflammatory and bone-resorbing cytokine tumor necrosis factor (TNF)-alpha (TNF- $\alpha$ ) is elevated in MM patients and correlated with MMBD. TNF- $\alpha$ sustains OC differentiation by directly targeting macrophages in a stromal environment expressing high levels of RANKL [51]. Furthermore, OCs produce B-cell activating factor (BAFF) and the proliferation-inducing ligand (APRIL), two members of tumor necrosis factor (TNF) family, which act as growth factors in MM cells, while MM cells in turn produce cytokines which stimulate the osteolytic activity in OCs [52].

In MM patients, upregulation of the cytokine activin A correlates with bone lesions and advanced disease. MM cells induce the production of activin A in BMSCs, partly through the JNK pathway. In turn, activin A inhibits OB differentiation by stimulating SMAD2 activity and inhibiting distal-less homeobox (DLX) -5 expression [53]. Blocking activin A signaling rescued MM-induced OB impairment, while reducing MM burden in a humanized murine model of MM [53]. Interestingly, activin A seems to be involved in bone remodeling also as an inducer of osteoclastogenesis, via stimulation of RANK expression and consequent enhancement of RANKL signaling [54].

An additional cytokine important in MMBD is the transforming growth factor $\beta$ (TGF $\beta$ ), that is produced in an inactive form by OBs in bone matrix and activated by OCs during bone resorption. During osteogenesis, TGF $\beta$ stimulates early OB proliferation, while blocking late-stage OB differentiation and mineralization to decrease bone formation [55]. TGF $\beta$ also increases bone lytic activity through stimulation of RANKL secretion and enhancement of OCs survival [56-60].

\section{NcRNAs and MMBD}

The non-coding compartment of the human genome represents almost the $98.5 \%$ of the whole human transcriptome. It has been widely demonstrated that ncRNAs critically regulate almost all physiologic and pathologic processes [61,62]. Based on their length, they have been classified into short ( $<200$ nucleotides) non-coding RNAs (sncRNAs) or long ( $>200$ nucleotides) non-coding RNAs (lncRNAs).

\subsection{Short Non-Coding RNAs}

MicroRNAs (miRNAs) are sncRNA molecules, of 17 to 24 nucleotides (nt) in length, that post-transcriptionally regulate mRNAs by perfect or partial complementarity to their $3^{\prime}$ untranslated region ( $3^{\prime}$ UTR), inducing either translational repression or degradation of target mRNAs. Since one miRNA can target hundreds mRNAs, it is obvious that these molecules have the capability to concomitantly regulate multiple pathways [63,64]. Dysregulation of miRNA expression and function has been shown to underlie the onset and progression of all cancer types, including PC dyscrasias [7]. 
Modulation of miRNA levels has been observed during MSCs differentiation both in physiological and pathological settings, with an emerging role also in the pathogenesis of MMBD. miRNAs involved in the MMBD pathophysiology and targeting the most relevant MMBD-related pathways will be discussed below. Figure 1 provides a graphic overview of mRNAs targeted by miRNAs and affecting osteoblastogenesis or osteoclastogenesis in MM.

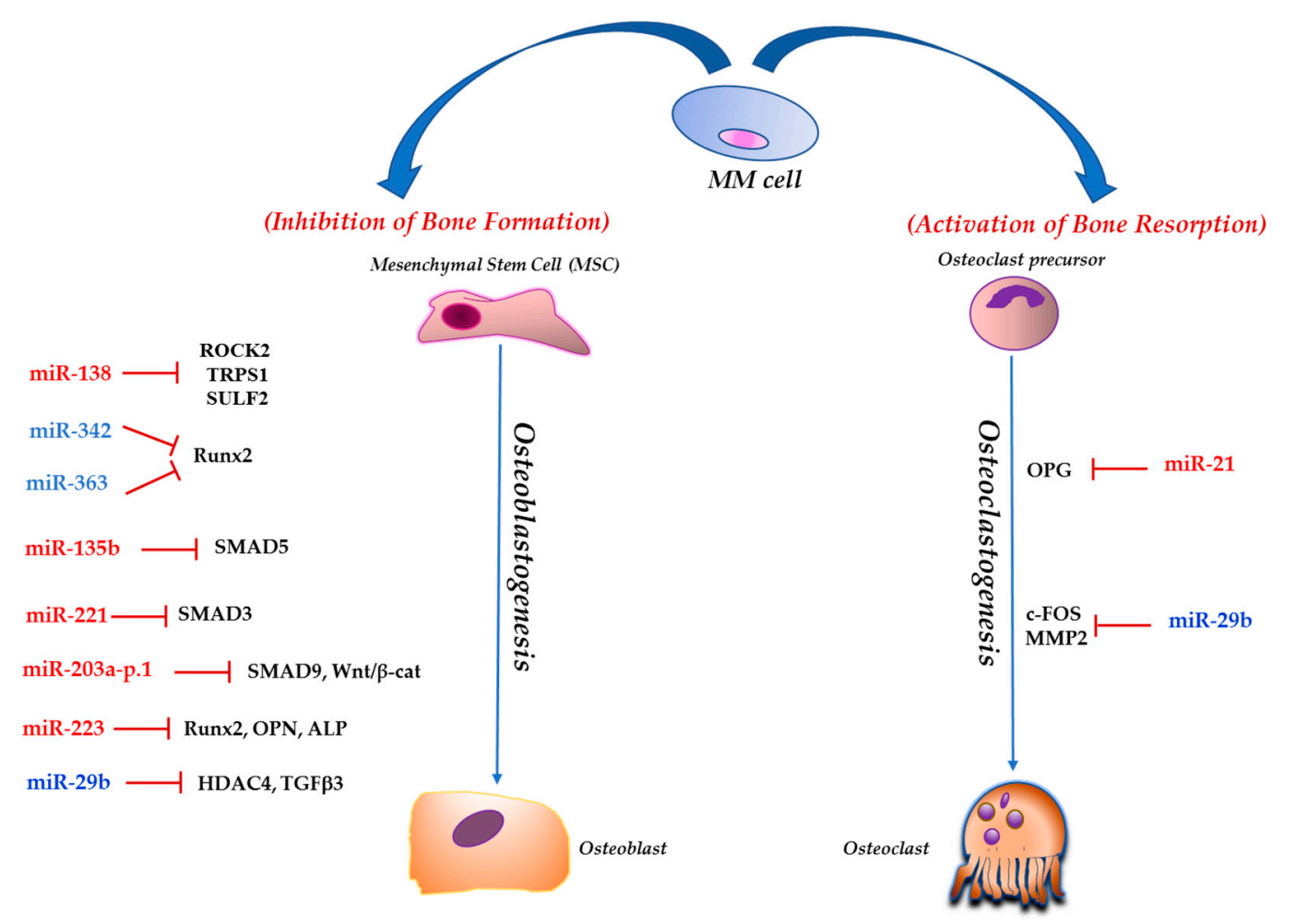

Figure 1. The picture reports microRNAs (miRNAs) and their corresponding mRNA targets involved in osteoblastogenesis and osteoclastogenesis processes in the multiple myeloma (MM) bone marrow microenvironment (BMM). miRNAs triggering bone resorption are reported in red; miRNAs triggering bone apposition are reported in blue.

\subsection{1. $\mathrm{miR}-221$}

The miR-221/222 cluster plays an oncogenic role in MM, where its inhibition induces significant anti-tumor activity by targeting key molecules involved in cell proliferation, survival and drug resistance as p27, p57 and PUMA [65-67]. The involvement of miR-221 in bone pathophysiology was initially suggested by its lower expression in osteoporotic compared with non-osteoporotic samples. Overexpression of miR-221 decreases the osteogenic potential of human mesenchymal stem cells (hMSCs), as indicated by the reduced expression levels of key OB markers, including osteocalcin (OC), alkaline phosphatase (ALP) and collagen, type I, $\alpha 1$ (COL1A1); conversely, miR-221 inhibition led to the opposite effects. Biochemical experiments demonstrated that miR-221 targets Runx2, whose ectopic expression rescued miR-221 effect on OB markers, supporting the notion that miR-221-mediated OB differentiation occurs in a Runx2-dependent manner. miR-221-5p expression declined during OB induction of normal MSCs, while it remained unchanged upon differentiation of myeloma-derived MSCs. Notably, miR-221-5p inhibition increased the osteogenic differentiation capacity of MMBD-MSCs, and this effect was ascribed to SMAD3 down-regulation and to the activation of the PI3K/AKT/mTOR signaling pathway [68]. 


\subsection{2. $\mathrm{miR}-138$}

miR-138 was first identified as a negative regulator of hMSC OB differentiation. In vitro, miR-138 inhibition enhanced OB differentiation of hMSCs, whereas miR-138 overexpression inhibited their osteogenic potential. Moreover, miR-138 antagonism increased, whereas miR-138 overexpression reduced bone formation [69]. Increased expression of miR-138 was observed in MM cells and in MM MSCs compared to that from healthy subjects; co-culture with MM cells upregulated miR-138 in healthy MSCs, suggesting that the interplay between MM cells and MSCs drives the dysregulated miR-138 expression in MSCs.

Interestingly, inhibition of miR-138 with an LNA-modified anti-miR-138 oligonucleotide was able to enhance the osteogenic differentiation of MSCs in vitro; moreover, bone formation rate and OBs number were significantly increased in MM bearing mice treated with anti-miR-138 LNA, indicating that miR-138 negatively regulates bone apposition in $\mathrm{MM}$. Gene set enrichment analysis performed on anti-miR-138-treated cells revealed that the regulation of chondrocyte differentiation gene set was enriched in the OBs inhibited for miR-138, suggesting that miR-138 antagonism induces bone formation in the context of MM by de-repressing target genes involved in osteochondrogenesis. Three putative miR-138 targets known to be important for the induction of osteogenic and chondrogenic MSC differentiation, namely ROCK2, TRPS1 and SULF2, were de-repressed after anti-miR-138 treatment [70].

\subsection{3. miR-203a-3p.1}

During osteoblastogenesis, miR-203a-3p.1 levels were found to decline in normal MSCs, whereas no change was observed in MM MSCs. In line with these findings, the authors demonstrated that canonic OB differentiation markers, including ALP, OPN and OC, were upregulated in MM-MSCs following treatment with anti-miR-203a-3p.1 oligonucleotides. The inhibitory effects on hMSCs osteogenic activity by miR-203a-3p.1 was likely dependent on the targeting of SMAD9 and of Wnt/ $\beta$-catenin pathway, which promote $\mathrm{OB}$ differentiation and bone formation; accordingly, rescue experiments confirmed the key role of SMAD9 down-regulation in miR-203a-3p-mediated osteoblastogenesis [71].

\subsection{4. $\mathrm{miR}-21$}

miR-21 is an established onco-miRNA in MM [72], where its expression is induced by IL-6 in a STAT3-dependent manner [73]. miR-21 was found upregulated in OCs [74] and in BM mononuclear cells of MM patients [75], supporting a role within the BM milieu. We previously showed that miR-21 plays a pivotal role in sustaining MMBD by regulating RANKL/OPG ratio in the MM BM microenvironment. Higher levels of miR-21 were found in MM BMSCs as compared with healthy BMSCs. Importantly, we validated OPG as a direct target of miR-21 and reported that selective inhibition of miR-21 in MM BMSCs was able to restore OPG expression and secretion and to reduce RANKL levels. As a result, miR-21 inhibition in BMSCs suppressed the bone lytic activity of OCs in vitro, thus pointing to miR-21 as candidate target to treat MMBD [76]. In MM, Th17 cells sustain tumor growth and OCs-dependent bone damage. We found that Th17 from MM patients with BD express significantly higher miR-21 levels as compared to non-osteolytic MM and healthy controls; importantly, early inhibition of miR-21 in naive T cells impaired Th17 differentiation in vitro and abrogated Th17-mediated MM cell proliferation and OCs activity. These findings were recapitulated in vivo in NOD/SCID- $\gamma$-NULL mice intratibially injected with T cells transfected with miR-21 synthetic inhibitors and MM cells. At a molecular level, a pairwise RNAseq and proteome/phosphoproteome analysis demonstrated that miR-21 inhibition in Th17 cells upregulated STAT-1/-5a-5b, impaired STAT-3 and redirected Th17 towards Th1/Th2 like activated/polarized cells [77].

\subsection{5. $\mathrm{miR}-29 \mathrm{~b}$}

Several reports indicate that the expression of miR-29 family members is widely deregulated in hematologic malignancies $[78,79]$, and their reconstitution deeply impacts on the phenotype of 
cancer cells through the targeting of epigenetic regulators [80-82]. miR-29b was found upregulated along osteoblastogenesis during late mineralization phases. Specifically, miR-29b overexpression turned off the expression of key OB-inhibitory proteins such as TGF 33 and HDAC4, resulting in Runx2 upregulation, and also down-regulated the Wnt pathway inhibitor catenin beta interacting protein 1 (CTNNBIP1) [83]. In parallel, our studies defined the role of miR-29b in the inhibition of OCs generation and function. In fact, we found that miR-29b was progressively down-regulated during OCs differentiation of monocyte precursors under M-CSF and RANK-L stimulation, and restoration of miR-29b expression in OCs precursors strongly antagonized OCs resorbing activity by reducing intracellular levels of TRAP, cathepsin K, metalloproteinase type 2 and 9 (MMP-2 and MMP-9). Reduced expression levels of such OC-resorbing enzymes were due to the targeting of MMP-2 and c-FOS mRNAs, which in turn impaired the rearrangement of actin rings, whose normal morphology is critical for OCs resorbing activity and bone adherence. Enforced expression of miR-29b also reduced RANK expression on the cell surface, hampering OCs response to RANKL stimulation and reducing in vitro osteoclastogenesis induced by MM cell lines [78,84]. Importantly, miR-29b levels were significantly reduced in MM dendritic cells, and its reconstitution counteracted pro-inflammatory pathways in co-cultured MM cells, including signal transducer and activator of transcription 3 and nuclear factor- $\mathrm{kB}$, and cytokine/chemokine signaling networks, which correlated with patients' adverse prognosis and development of BD. Moreover, miR-29b downregulated IL-23 in vitro and in the SCID-synth-hu in vivo model, and antagonized a Th17-driven inflammatory response, which notably sustains MM cell growth and osteoclast-dependent bone damage [85].

\subsection{6. $\mathrm{miR}-214$}

miR-214 was found implicated in physiological processes, as osteogenesis, osteoclastogenesis and muscle development, as well as in pathological conditions. Misiewicz-Krzeminska et al. demonstrated the down-regulation and the tumor suppressor roles of miR-214 in MM cells. Restoration of miR-214 expression level in MM cells enhanced apoptosis and the inhibition of cellular proliferation, through the inhibition of p53/MDM2 interaction and of the DNA replication pathway [86]. By analyzing the expression profile of miRNAs on a large cohort of MM patients with different stages of $\mathrm{BD}$, Hao and colleagues showed that circulating miR-214 in the serum of MM patients significantly correlated with the degree of bone injury, and MM patients with a higher level of serum miR-214 had a poor outcome. In addition, miR-214 levels in MM patients with lytic bone lesions were higher than those without bone lesions. Indeed, patients with high serum miR-214 levels showed a significant reduction in progression-free survival (PFS) and overall survival (OS). On the other hand, when treated with bisphosphonates MM patients presenting higher miR-214 serum level benefited from a significant increase in their quality of survival, with effects on reduction of bone lesions rather than on tumor burden. According to these data, miR-214 levels in patients serum may be used as biomarkers for the detection of MMBD, as well as prognostic markers for MM patients with BD to define the start of treatment with bisphosphonates [87].

\subsection{7. $\mathrm{miR}-135 \mathrm{~b}$}

Abnormal expression of miR-135b is reported in different types of tumors, with a clear role in tumorigenesis. As reported by $\mathrm{Xu}$ et al., miR-135b is involved in MMBD impairing the osteogenic differentiation capability of BM-derived MSCs from MM patients (MM-hMSCs) by targeting at 3' UTR SMAD5, which is involved in osteogenesis. Upregulation of miR-135b in MM BM-derived hMSCs causes a reduction of ALP activity. On the other side, miR-135b inhibition in MM-hMSCs maintained in osteogenic medium restored the activity of ALP and of other osteogenic markers (BSP, COLA1 and OPN). The increase of miR-135b also was observed during co-culture of hMSCs from healthy donors with MM cells lines, indicating that the MM microenvironment modulates the miRNome of hMSCs reducing their osteogenic potential [88]. This may explain why Hao and colleagues observed dysregulated levels of miR-135b in the serum of the MM patients, which could be used to distinguish 
patients with or without bone lytic lesions [87]. Therefore, miR-135b inhibitors may represent potential RNA therapeutics to direct hMSC osteogenic differentiation towards bone formation [88].

\subsection{8. $\mathrm{miR}-342$ and $\mathrm{miR}-363$}

High levels of the bone-specific transcription factor Runx2 is observed in several solid tumors, promoting bone metastasis and osteolysis [43,89]. Recently, some studies have reported that MM cells release soluble factors to suppress osteoblastogenesis through Runx2 inhibition in immature and pre- OBs at new bone sites [90]. By comparing the plasma of MM patients with normal donors, Gowda et al. showed that high levels of Runx2 in MM cells inversely correlated with miR-342 and miR-363 expression. Overexpression of miR-342 and miR-363 in CAG MM cells, individually or in combination, suppressed Runx2 protein levels, with concomitant inhibition of $\mathrm{Akt} / \beta$-catenin/survivin, known targets of Runx2, leading to a strong reduction of MM cell proliferation. The combined miRNAs action on MM cells also led to a decrease of DKK1 and RANKL levels both in in vitro and in vivo preclinical models. In MM-bearing mice, miR-342 and miR-363 acted on the BMM by increasing OB and decreasing OC numbers, antagonizing bone resorption in vivo. Moreover, overexpression of miRNAs led to an improvement of anti-tumor immunity in vivo, increasing the number of immunosuppressive regulatory $\mathrm{T}$ and $\mathrm{B}$ cells and decreasing dendritic cells within the tumor microenvironment [89].

\subsection{9. $\mathrm{miR}-223$}

miR-223 was identified as a key regulator for differentiation of myeloid precursors and OCs. In cancer, deregulation of miR-223 was described in leukemia and lymphomas [91,92]. Evidence of a miR-223 tumor supportive role was reported in MM, where its expression in MSCs decreased in a cell-adhesion dependent manner [93]. Co-culture of MM cells and MM-MSCs induced activation of Notch signaling via jagged-2/notch-2, leading to increased expression of Hes1, Hey2, or Hes5 in both cell types; in turn, activation of Notch signaling in MM-MSCs led to a decrease in miR-223 expression, although the underlying mechanism was not addressed. To support role of Notch signaling on the miR-223 decrease, the authors demonstrated that Notch pathway inhibition either through the $\gamma$-secretase inhibitor GSI-XII or a jagged-2 neutralizing antibody, upregulated miR-223 levels. Of note, this study also highlighted the role of miR-223 in the osteogenic differentiation of MSCs; in fact, miR-223 levels significantly increased when osteogenic differentiation was induced. Moreover, inhibition of miR-223 expression impaired the osteogenic differentiation potential of MSCs, decreasing the expression of Runx2 and osteopontin, and reducing ALP activity and calcification [93].

\subsection{Long Non-Coding RNAs}

Long non-coding RNAs refer to a highly heterogeneous class of non-coding RNAs longer than $200 \mathrm{nt}$, that include intergenic transcripts (lincRNAs), enhancer RNAs (eRNAs) and sense or antisense transcripts that overlap other genes [94]. They have been found implicated in several molecular functions, including in cis or in trans transcriptional regulation, organization of nuclear domains and regulation of proteins and/or RNA molecules; functionally, they can act as guides for ribonucleoprotein complexes, dynamic scaffolds and molecular decoys for proteins including transcription factors and miRNA sponges [7,94-96].

Overall, IncRNAs play crucial roles in several cellular processes, such as DNA repair, proliferation, angiogenesis and epithelial-mesenchymal transition; moreover, their expression is linked with various diseases and some of them have been described as potential disease biomarkers [97-101]. Indeed, numerous lncRNAs have been described as aberrantly expressed in various cancers and/or associated with clinically relevant cancer subtypes, predicting tumor behavior and prognosis [102,103]. Recent studies have clarified the expression profiles of lncRNAs in PC dyscrasias [7,104,105]. In MM, three distinct transcriptomic analyses unraveled a dysregulated lncRNA landscape. Ronchetti et al. used microarray technology to analyze lncRNA expression in patients at different stages of MM progression—including MGUS, sMM, MM and PCL—and in healthy donors, identifying 31 lncRNAs 
altered in tumor samples [106]. RNA-seq was used by the same authors in a follow-up study, to evaluate lncRNA expression in $30 \mathrm{MM}$ patients, leading to the identification of 391 dysregulated lncRNAs, and also extended the study to the main MM molecular subgroups and genetic alterations [107]. Samur et al. instead described the lncRNA landscape in MM cells by RNA-seq on PCs from 308 newly-diagnosed and uniformly treated MM patients enrolled to the DFCI/IFM 2009 clinical study, and developed a prognostic model based on IncRNAs to stratify patient risk [108].

Since several lncRNAs have been already described for their role in bone metabolism and osteogenesis, they have also been investigated for their potential role in MMBD [104]. Collectively, functional investigations on IncRNAs in the context of MMBD are limited respect to miRNAs, and this gap is likely dependent on their complex 3D structure interacting with various molecular partners, leading to a pleiotropic activity which makes them difficult to study [7].

A recent study evaluated 17 lncRNAs, whose targets were described as crucial molecules in $\mathrm{MM}$ and bone homeostasis; analysis was carried out in MM patients with bisphosphonate-induced osteonecrosis of the jaw (BONJ), in MM patients without BONJ and in a group of healthy controls. Results obtained evidenced a different lncRNA profile in BONJ patients compared to MM patients and controls. Notably, two lncRNAs (DANCR and metastasis associated in lung adenocarcinoma transcript 1 (MALAT1)) resulted downregulated when compared to controls and MM, while twelve were found overexpressed in MM with BONJ. Overall, the authors suggested that targeting these IncRNAs could represent a valuable tool for prevention and therapy of BONJ [109].

The most relevant lncRNAs found which are potentially implicated in MMBD pathophysiology are below summarized.

\subsubsection{LncHOXC-AS3}

As stated above, MMBD is characterized by severely impaired osteogenesis [5]. The lncRNA HOXCAS3 is transcribed in opposite to HOXC10 and positioned at chromosome 12q13.13; in MM it is expressed in MM MSCs.

HOXC-AS3 interacts with HOXC10 at the overlapping parts thus strengthening its stability and promoting its expression; consequently, up-regulation of HOXC10 contributed to repressing osteogenic potential of MSCs [110]. The effect of HOXC-AS3 on osteogenic differentiation was evaluated in vivo, by using a "human-in-mouse" xeno-transplantation MM model, which included the MM clinical signs such as $\mathrm{BD}$. To analyze bone loss in the mouse models, trabecular and cortical bone were evaluated by micro CT images; results obtained indicated severe bone loss in the vehicle control group, compared to the HOXC-AS3 siRNA-treated mice group. In addition, HOXC-AS3 siRNA significantly altered bone turnover markers levels in serum; in particular, the bone resorption marker C-terminal telopeptide of type 1 collagen (CTX) was reduced in HOXC-AS3 siRNA group, while the bone formation marker, procollagen type $1 \mathrm{~N}$-terminal propeptide (P1NP), increased [110].

\subsubsection{TUG1}

The taurine upregulated gene 1 (TUG1) lncRNA contributes to the formation of photoreceptors and plays crucial roles in retinal development [111]. TUG1 is a $7.1 \mathrm{~kb}$ lncRNA transcribed from human chromosome 22q12.2. Different works have reported that TUG1 has pro-tumor activity in several tumors, such as osteosarcoma, melanoma, cholangiocarcinoma [112], glioma and hepatocellular carcinoma, non-small cell lung cancer and bladder cancer [113]. Recently, through qRT-PCR analysis of serum samples from 98 healthy controls and $110 \mathrm{MM}$ patients, Qingqing et al. observed increased TUG1 levels in MM. To explore the diagnostic utility of TUG1, they compared TUG1 expression levels in different stages of disease in MM patients, alone or together with other diagnostic biomarkers such as albumin and $\beta 2$-microglobulin. Univariate analyses confirmed the correlation of TUG1 levels with different disease stages in MM, observing a higher serum TUG1 level in patients with bone lesion. Furthermore, the multivariate analysis combining all three biomarkers significantly improved the AUC value of ROC analysis, which was better than any individual marker analysis. These results suggested 
the usefulness of TUG1 as a potential diagnostic biomarker suitable for clinical use [114], although its functional role within MMBD remains to be investigated.

\subsubsection{MALAT1}

The lncRNA metastasis associated in lung adenocarcinoma transcript 1 , which is located on the human chromosome 11q13, has a total length of about $8 \mathrm{~kb}$. MALAT1 regulates the transcriptional and translational levels of proto-oncogene Runx2 in colorectal cancer metastasis [115]. It is expressed in different tissues where it regulates gene expression, alternative splicing and cell cycle. MALAT1 has been found overexpressed in several human neoplasms and promotes tumor cell invasion and metastasis $[116,117]$. Cho et al. first investigated the relationship between MALAT1 and MM disease. They evaluated MALAT1 expression by comparing the mononuclear bone marrow cells of MM patients in different disease states compared to healthy individuals, and demonstrated that the high serum levels of MALAT1 detected in MM patients decreased significantly in post-treatment patients, showing serum levels similar to those of healthy individuals and a prolonged progression-free survival [118]. We studied MALAT1 functional role in MM and demonstrated that it may promote cell survival by regulating the expression and activity of the proteasome machinery [119]. Regarding its role in normal bone homeostasis, Xiao et al. demonstrated that MALAT1 promotes osteoblastogenesis via miR-204 sponging, and upregulating the miR-204-target SMAD4, which in turn promoted the expression of ALP and osteocalcin responsible of the increased bone formation and mineralization [120]; however, MALAT1 functional role in MMBD has not been, so far, investigated.

\subsubsection{MEG3}

Zhuang et al. found that the IncRNA maternally expressed gene 3 (MEG3), which is located on 14q32.2, promotes the differentiation of MM BMSCs into OBs. Mechanistically, MEG3 promotes the translation of the downstream BMP4 gene by preventing the inhibitory effect of SOX2 on the BMP4 promoter [121]. Conversely, Li et al. showed that MEG3 is downregulated during adipose-derived MSC differentiation into adipogenic cells, while upregulated during osteogenic differentiation. Interestingly, MEG3 silencing promoted the osteogenic and adipogenic differentiation of human adipose-derived MSCs [122]. Additional studies are indeed required to clarify the role of MEG3 in MMBD pathophysiology.

\subsection{Circular RNAs}

Circular RNAs (circRNAs) are covalently closed single-stranded lncRNAs whose expression is finely regulated in a tissue- and disease-specific manner. They can act as modulators of transcription, as miRNA sponges or can even sequester factors, such as RNA-binding proteins or ribonucleoprotein complexes [123]; of note, they can be also packaged and released into extracellular vesicles (EVs) [124]. Emerging evidence has highlighted that circRNAs are implicated in various malignancies and can function as potential diagnostic and prognostic biomarkers [125-128]. High-throughput RNA sequencing has recently revealed thousands of circRNAs expressed in different cancer cell lines [129]. Collectively, few studies have been addressed in MM [130-133]. Dahl et al. [127] identified 619 unique circRNAs in the MM cell line NCI-H929. By RNA-seq, Liu et al. identified circRNAs differentially expressed in MM patients respect to the healthy individuals, focusing on hsa_circRNA_101237, that positively correlated with some clinical features of MM patients, including bone destruction [132]. Upregulation of hsa_circRNA_101237 in recurrent/refractory patients compared to first-episode treatment-naive patients was shown; similar results were obtained after analysis of expression levels of hsa_circRNA_101237 in different MM cells lines, with the highest expression levels of hsa_circRNA_101237 observed in bortezomib resistant cell lines. They also analyzed the correlation between hsa_circRNA_101,237 expression levels and MM types or bone lesions, chromosomal variations and genetic variations. Interestingly, it was found that hsa_circRNA_101237 was overexpressed in positive patients for 13q14 deletion, 1q21 amplification, P53 deletion and $t(4,14)$ and $t(14,16)$, along with 
KRAS, NRAS, FAM46C, DIS3, BRAF, TRAF3 and TP53 gene mutations, associated with poor prognosis of MM patients. In particular, the overexpression of hsa_circRNA_101237 was closely related in MM patients with cytogenetic abnormalities and BD, which were of R-ISS stage III, defining it as a marker of high clinical value [132]. The mechanistic role of this circRNA in the context of MM and MMBD is yet to be analyzed.

\section{Extracellular Vesicle-Associated ncRNAs}

It has been widely demonstrated that different ncRNAs species are contained in extracellular vesicles, which are lipoproteic structures heterogeneous in size and content, released by almost all cell types $[134,135]$. In recent years, EVs have gained attention because of the identification of biological molecules as cargo. In fact, if they were initially considered a way of elimination of waste products [136], current knowledge indicates that EVs represent a cell-cell means of communication.

EVs play a crucial role in the context of MM pathobiology, and specifically in the crosstalk that malignant PCs establish with other cells of the BMM such as endothelial, stromal, MSCs and immune cells [137-142]. Such interaction is key both in the progression of the disease and in the onset of pharmacological resistance $[143,144]$. Moreover, growing experimental evidence indicates that EVs released by MM cells alter bone homeostasis and, therefore, contribute to the onset of MMBD [145-149].

We firstly demonstrated that EVs were released from MM cell lines and were also detectable in the serum of MM patients. Such EVs induced the osteoclastic differentiation of murine macrophages as well as of human pre-osteoclasts, enhancing the expression of specific OC differentiation markers, such as CTSK, MMP9 and TRAP. MM-EVs were able to induce a complete osteoclastic differentiation. Notably, pre-osteoclast treated with MM-EVs differentiated in multinuclear and giant OCs, having a strong erosive capability, as evidenced by bone resorption pit assays; these effects were not observed when EVs derived by the metastatic colorectal cancer cell line SW620 were used, demonstrating the MM cell-type specificity of EVs within the BMM [145].

Subsequently, many studies have disclosed the molecular mechanisms underlying the EV-dependent osteoclastogenic effect. In 2019, Raimondo et al. showed that the presence of the EGFR ligand, amphiregulin (AREG), partially mediates the EV-mediated OC activation. Authors observed that AREG was specifically enriched in exosome samples, leading to the activation of EGFR in pre-OCs; such effects were abrogated by exosome pre-treatment with anti-AREG neutralizing Ab [146].

In parallel, the role of EVs on another crucial cell population involved in bone homeostasis, i.e., OBs, has been investigated. The results of these studies indicate that MM EVs can inhibit the osteogenic differentiation of MSCs, thus contributing to increased osteolysis [146-148,150-152]. In one of these studies, it emerged that MM EVs carry DKK1 in OBs leading to reduced levels of Runx2, osterix and collagen 1A1 [152].

Noteworthy, increasing evidence suggests that the EV-associated ncRNA cargo mediates the profound impact that EVs exert on the gene expression profile of target cells [153-155].

Research has been performed to identify the mechanisms underlying the specific sorting of certain ncRNAs in EVs. For some miRNAs, a small sequence, called hEXO motif, has been identified as recognized by the RNA binding protein SYNCRIP, and found to be responsible for the specific sorting of these miRNAs in vesicles [156].

Recent evidence also correlated the osteolytic effect of MM-EVs with its ncRNAs content. A study published by Li et al., showed that the IncRNA RUNX2-AS1 is packaged in MM-EVs and transferred to MSCs, resulting in the transcriptional repression of Runx2 and, thus, prematurely blocking MSCs osteogenic differentiation [147]. Finally, by analyzing the miRNA repertoire of MM-EVs, several miRNAs involved in the inhibition of osteogenic differentiation $[148,149]$ were identified. In a recent study, miR-103a-3p was identified as one of the upregulated miRNAs following the treatment of MSCs with MM-EVs [148]; in parallel, miR-129-5p, carried by MM-EVs, was found to reduce ALPL levels in MSCs. In addition, the authors also observed that miR-129-5p was more abundant in EVs isolated from 
MM patients with active BD than in SMM, supporting the notion that this miRNA is key in mediating the EV-dependent MMBD [149].

A more in-depth characterization of the ncRNAs contained in these structures will allow the development of new biomarkers for the diagnosis and prognosis of the disease. In parallel, the identification of the mechanisms underlying the exact sorting of ncRNAs, and/or other biomolecules, in EVs, could provide the basis for the definition of new therapeutic targets against MMBD.

\section{Conclusions}

Preclinical studies have clarified the pathophysiology of MMBD identifying new possible druggable targets, which could hopefully enlarge the spectrum of therapeutic opportunities against this severe MM complication. In this context, a novel area of investigation is represented by ncRNA molecules, which can finely tune the gene expression programs of BMM cells finally regulating bone homeostasis. ncRNAs have been found to be expressed and secreted within EVs by various cellular components of the BMM. By modulating the expression of signaling molecules implicated in OC development, ncRNAs have been demonstrated to control different processes in OCs precursors and mature OCs. A graphic overview of the molecular and cellular scenario underlying MMBD pathophysiology and overall reviewed in this manuscript is reported in Figure 2. Collectively, available literature findings presented in this review point to a promising role of these molecules as novel therapeutic and prognostic tools in MMBD, able to affect the expression of some of the most important MMBD-related pathways. However, it has to be noticed that although the prognostic relevance of ncRNAs different from miRNAs (i.e., lncRNAs, circRNAs) is progressively emerging, functional studies clarifying their biological activity are at their infancy or still missing and need to be mandatorily performed to dissect their precise role in MMBD. Moreover, lncRNA expression profiling of BMM cells under specific differentiation stimuli is warranted to identify useful lncRNA signatures to be functionally characterized in the context of MMBD.

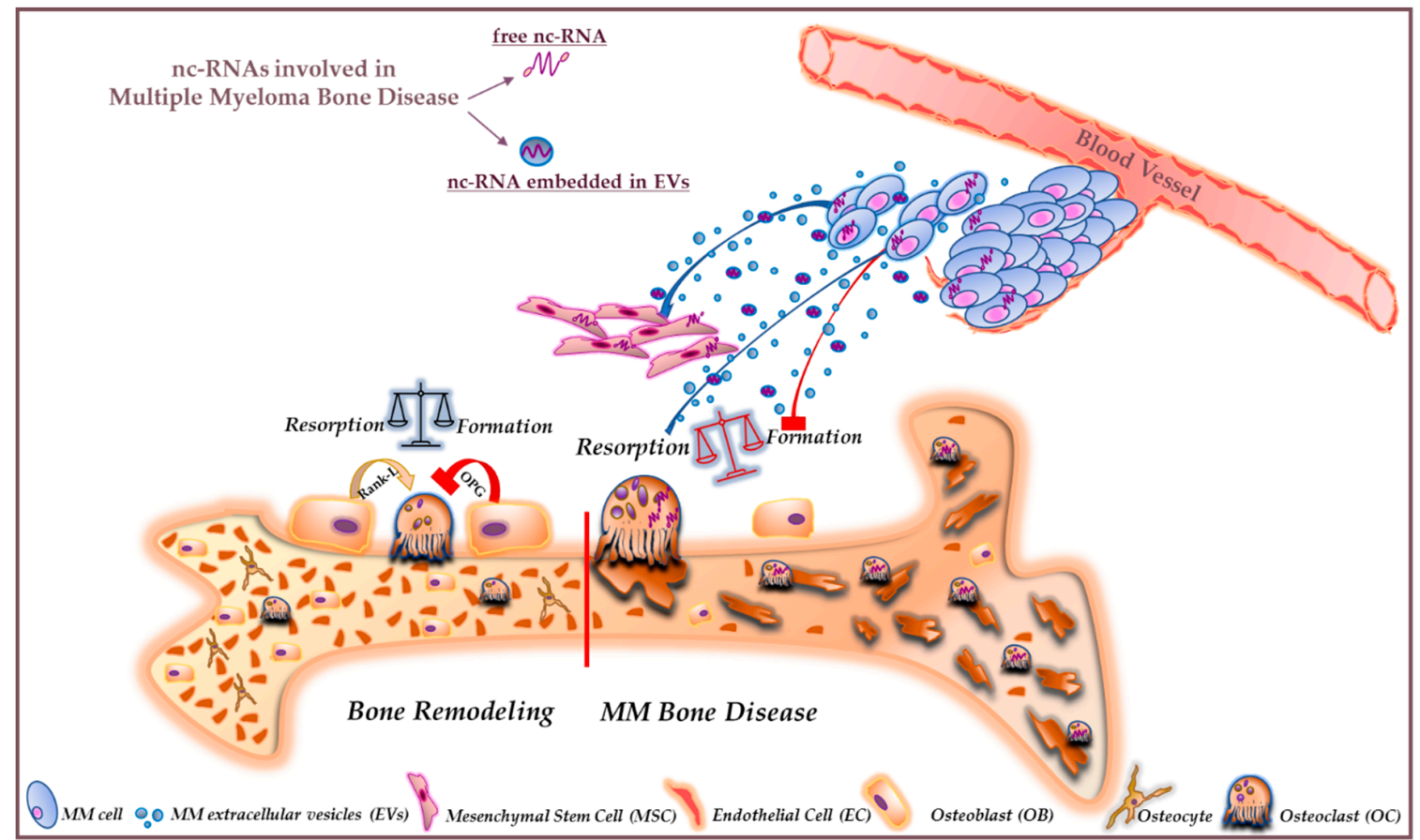

Figure 2. Cartoon showing the effect of dysregulated non-coding RNAs (ncRNAs) (miRNAs and long (>200 nucleotides) non-coding RNAs (lncRNAs)) on multiple myeloma bone disease (MMBD). ncRNAs modulate bone remodeling both in physiologic conditions (on the left side of the red line across the bone) or in MM (on the right side of the red line across the bone). Under physiologic conditions, 
osteoclasts (OCs) and osteoblasts (OBs) work together to balance bone resorption and formation. Their activities are governed by specific gene programs, whose expression is regulated by ncRNAs, i.e., miRNA or lncRNAs produced by MM cells and/or other cells of the BMM, and released within extracellular vesicles (EVs). In MMBD, dysregulated ncRNAs contribute to enhance OCs activity for instance acting on RANKL/OPG pathway, while OB activity is inhibited, thus establishing an unbalanced condition that fosters the development of osteolytic lesions.

The most relevant ncRNAs functionally implicated in MMBD, their main molecular targets and their bone-related effects are summarized in Table 1.

Table 1. Molecular targets and bone-related effects of functionally characterized ncRNAs in MMBD.

\begin{tabular}{|c|c|c|c|c|}
\hline ncRNAs & $\begin{array}{l}\text { Target(s) in } \\
\text { MMBD }\end{array}$ & Bone-Related Effects & $\begin{array}{l}\text { Function in } \\
\text { MMBD }\end{array}$ & Reference(s) \\
\hline hsa-miR-221 & SMAD3 & $\begin{array}{c}\text { Decreases the osteogenic potential } \\
\text { of hMSCs }\end{array}$ & oncomiRNA & {$[68]$} \\
\hline hsa-miR-138 & $\begin{array}{l}\text { ROCK2, TRPS1 } \\
\text { and SULF2 }\end{array}$ & $\begin{array}{l}\text { Decreases the osteogenic and } \\
\text { chondrogenic potential of hMSCs }\end{array}$ & oncomiRNA & {$[69,70]$} \\
\hline hsa-miR-203a-3p.1 & $\begin{array}{l}\text { SMAD9 and } \\
\text { Wnt/ } \beta \text {-catenin } \\
\text { pathway }\end{array}$ & $\begin{array}{c}\text { Decreases the osteogenic potential } \\
\text { of hMSCs }\end{array}$ & oncomiRNA & {$[71]$} \\
\hline hsa-miR-21 & OPG & $\begin{array}{l}\text { Regulates RANKL/OPG ratio in } \\
\text { the MM BM microenvironment }\end{array}$ & oncomiRNA & {$[76,77]$} \\
\hline hsa-miR-29b & c-FOS; MMP2 & $\begin{array}{l}\text { Negatively regulates human OCs } \\
\text { differentiation and function }\end{array}$ & TS miRNA & {$[84,85]$} \\
\hline hsa-miR-135b & SMAD5 & $\begin{array}{l}\text { Impairs the osteogenic } \\
\text { differentiation capability of } \\
\text { BM-derived MSCs from } \\
\text { MM patients }\end{array}$ & oncomiRNA & [88] \\
\hline $\begin{array}{l}\text { hsa-miR-342 and } \\
\text { miR-363 }\end{array}$ & Runx2 & $\begin{array}{c}\text { Impact the BMM decreasing OBs } \\
\text { activity and increasing } \\
\text { OCs activity }\end{array}$ & TS miRNA & [89] \\
\hline hsa-miR-223 & $\begin{array}{l}\text { Runx2 } \\
\text { Osteopontin }\end{array}$ & $\begin{array}{l}\text { Impairs the osteogenic } \\
\text { differentiation potential of } \\
\text { MM-BMMSCs }\end{array}$ & TS miRNA & [93] \\
\hline HOXC-AS3 & HOXC10 & $\begin{array}{l}\text { Represses the osteogenic potential } \\
\text { of MSCs }\end{array}$ & $\begin{array}{l}\text { Oncogenic } \\
\text { lncRNA }\end{array}$ & [110] \\
\hline MEG3 & BMP4 & $\begin{array}{l}\text { Promotes the differentiation of } \\
\text { MSCs into OBs }\end{array}$ & TS lncRNA & [121] \\
\hline
\end{tabular}

TS, tumor suppressor.

Author Contributions: Conceptualization, N.A. and L.R.; writing-original draft preparation, N.A., L.R., A.D.L., S.R., A.G., E.T., M.R., R.A., G.G., A.N., G.V. and N.A.; review and editing, N.A. All authors have read and agreed to the published version of the manuscript.

Funding: Nicola Amodio received a grant from Italian Ministry of Health (GR-2016-02361523). Riccardo Alessandro and Antonino Neri received grants from the Fondazione AIRC per la Ricerca sul Cancro (grant $n^{\circ} 18783$ to R.A. and $n^{\circ} 16722$ to A.N.).

Acknowledgments: Stefania Raimondo is supported by PON “Ricerca e Innovazione” 2014-2020-Azione 1.2459 "Mobilità dei Ricercatori" - AIM "Attraction and International Mobility".

Conflicts of Interest: The authors declare no conflict of interest. 


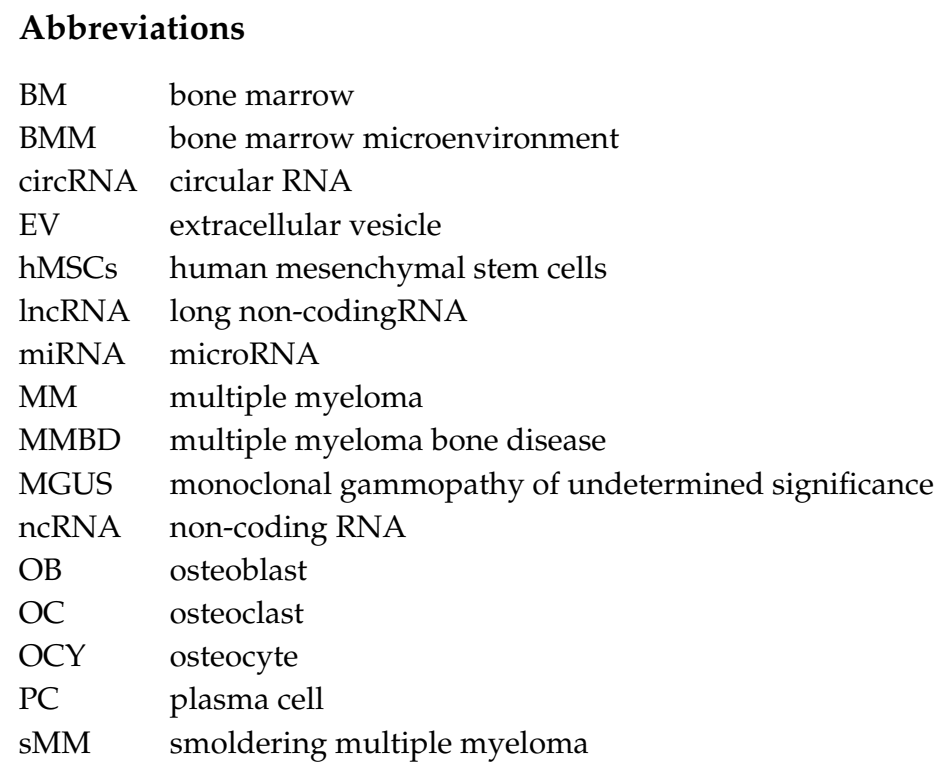

\section{References}

1. Terpos, E.; Ntanasis-Stathopoulos, I.; Gavriatopoulou, M.; Dimopoulos, M.A. Pathogenesis of bone disease in multiple myeloma: From bench to bedside. Blood Cancer J. 2018, 8, 7. [CrossRef]

2. Lemaire, M.; Deleu, S.; De Bruyne, E.; Van Valckenborgh, E.; Menu, E.; Vanderkerken, K. The microenvironment and molecular biology of the multiple myeloma tumor. Adv. Cancer Res. 2011, 110, 19-42. [CrossRef] [PubMed]

3. Raje, N.; Roodman, G.D. Advances in the biology and treatment of bone disease in multiple myeloma. Clin. Cancer Res. 2011, 17, 1278-1286. [CrossRef] [PubMed]

4. Raimondi, L.; De Luca, A.; Morelli, E.; Giavaresi, G.; Tagliaferri, P.; Tassone, P.; Amodio, N. MicroRNAs: Novel Crossroads between Myeloma Cells and the Bone Marrow Microenvironment. BioMed Res. Int. 2016, 2016, 6504593. [CrossRef] [PubMed]

5. Adamik, J.; Galson, D.L.; Roodman, G.D. Osteoblast suppression in multiple myeloma bone disease. J. Bone Oncol. 2018, 13, 62-70. [CrossRef]

6. Terpos, E.; Christoulas, D.; Gavriatopoulou, M. Biology and treatment of myeloma related bone disease. Metabolism 2018, 80, 80-90. [CrossRef] [PubMed]

7. Morelli, E.; Gullà, A.; Rocca, R.; Federico, C.; Raimondi, L.; Malvestiti, S.; Agosti, V.; Rossi, M.; Costa, G.; Giavaresi, G.; et al. The Non-Coding RNA Landscape of Plasma Cell Dyscrasias. Cancers 2020, 12, 320. [CrossRef] [PubMed]

8. Pearse, R.N.; Sordillo, E.M.; Yaccoby, S.; Wong, B.R.; Liau, D.F.; Colman, N.; Michaeli, J.; Epstein, J.; Choi, Y. Multiple myeloma disrupts the TRANCE/osteoprotegerin cytokine axis to trigger bone destruction and promote tumor progression. Proc. Natl. Acad. Sci. USA 2001, 98, 11581-11586. [CrossRef] [PubMed]

9. Heider, U.; Langelotz, C.; Jakob, C.; Zavrski, I.; Fleissner, C.; Eucker, J.; Possinger, K.; Hofbauer, L.C.; Sezer, O. Expression of receptor activator of nuclear factor kappaB ligand on bone marrow plasma cells correlates with osteolytic bone disease in patients with multiple myeloma. Clin. Cancer Res. 2003, 9, 1436-1440.

10. Terpos, E.; Szydlo, R.; Apperley, J.F.; Hatjiharissi, E.; Politou, M.; Meletis, J.; Viniou, N.; Yataganas, X.; Goldman, J.M.; Rahemtulla, A. Soluble receptor activator of nuclear factor kappaB ligand-osteoprotegerin ratio predicts survival in multiple myeloma: Proposal for a novel prognostic index. Blood 2003, 102, 1064-1069. [CrossRef]

11. Colombo, M.; Galletti, S.; Garavelli, S.; Platonova, N.; Paoli, A.; Basile, A.; Taiana, E.; Neri, A.; Chiaramonte, R. Notch signaling deregulation in multiple myeloma: A rational molecular target. Oncotarget 2015, 6, 26826-26840. [CrossRef] [PubMed]

12. Meurette, O.; Mehlen, P. Notch Signaling in the Tumor Microenvironment. Cancer Cell 2018, 34, 536-548. [CrossRef] [PubMed]

13. Benedito, R.; Roca, C.; Sörensen, I.; Adams, S.; Gossler, A.; Fruttiger, M.; Adams, R.H. The notch ligands Dll4 and Jagged1 have opposing effects on angiogenesis. Cell 2009, 137, 1124-1135. [CrossRef] [PubMed] 
14. Zanotti, S.; Smerdel-Ramoya, A.; Stadmeyer, L.; Durant, D.; Radtke, F.; Canalis, E. Notch inhibits osteoblast differentiation and causes osteopenia. Endocrinology 2008, 149, 3890-3899. [CrossRef] [PubMed]

15. Houde, C.; Li, Y.; Song, L.; Barton, K.; Zhang, Q.; Godwin, J.; Nand, S.; Toor, A.; Alkan, S.; Smadja, N.V.; et al. Overexpression of the NOTCH ligand JAG2 in malignant plasma cells from multiple myeloma patients and cell lines. Blood 2004, 104, 3697-3704. [CrossRef] [PubMed]

16. Colombo, M.; Mirandola, L.; Platonova, N.; Apicella, L.; Basile, A.; Figueroa, A.J.; Cobos, E.; Chiriva-Internati, M.; Chiaramonte, R. Notch-directed microenvironment reprogramming in myeloma: A single path to multiple outcomes. Leukemia 2013, 27, 1009-1018. [CrossRef] [PubMed]

17. Bai, S.; Kopan, R.; Zou, W.; Hilton, M.J.; Ong, C.T.; Long, F.; Ross, F.P.; Teitelbaum, S.L. NOTCH1 regulates osteoclastogenesis directly in osteoclast precursors and indirectly via osteoblast lineage cells. J. Biol. Chem. 2008, 283, 6509-6518. [CrossRef]

18. Pisklakova, A.; Grigson, E.; Ozerova, M.; Chen, F.; Sullivan, D.M.; Nefedova, Y. Anti-myeloma effect of pharmacological inhibition of Notch/gamma-secretase with RO4929097 is mediated by modulation of tumor microenvironment. Cancer Biol. Ther. 2016, 17, 477-485. [CrossRef]

19. Fukushima, H.; Nakao, A.; Okamoto, F.; Shin, M.; Kajiya, H.; Sakano, S.; Bigas, A.; Jimi, E.; Okabe, K. The association of Notch2 and NF-kappaB accelerates RANKL-induced osteoclastogenesis. Mol. Cell Biol. 2008, 28, 6402-6412. [CrossRef]

20. Yamada, T.; Yamazaki, H.; Yamane, T.; Yoshino, M.; Okuyama, H.; Tsuneto, M.; Kurino, T.; Hayashi, S.; Sakano, S. Regulation of osteoclast development by Notch signaling directed to osteoclast precursors and through stromal cells. Blood 2003, 101, 2227-2234. [CrossRef] [PubMed]

21. Spaan, I.; Raymakers, R.A.; van de Stolpe, A.; Peperzak, V. Wnt signaling in multiple myeloma: A central player in disease with therapeutic potential. J. Hematol. Oncol. 2018, 11, 67. [CrossRef] [PubMed]

22. Kimelman, D.; Xu, W. Beta-catenin destruction complex: Insights and questions from a structural perspective. Oncogene 2006, 25, 7482-7491. [CrossRef] [PubMed]

23. Zeng, X.; Huang, H.; Tamai, K.; Zhang, X.; Harada, Y.; Yokota, C.; Almeida, K.; Wang, J.; Doble, B.; Woodgett, J.; et al. Initiation of Wnt signaling: Control of Wnt coreceptor Lrp6 phosphorylation/activation via frizzled, dishevelled and axin functions. Development 2008, 135, 367-375. [CrossRef] [PubMed]

24. Städeli, R.; Hoffmans, R.; Basler, K. Transcription under the control of nuclear Arm/beta-catenin. Curr. Biol. 2006, 16, R378-R385. [CrossRef]

25. Bennett, C.N.; Longo, K.A.; Wright, W.S.; Suva, L.J.; Lane, T.F.; Hankenson, K.D.; MacDougald, O.A. Regulation of osteoblastogenesis and bone mass by Wnt10b. Proc. Natl. Acad. Sci. USA 2005, 102, 3324-3329. [CrossRef]

26. Almeida, M.; Han, L.; Bellido, T.; Manolagas, S.C.; Kousteni, S. Wnt proteins prevent apoptosis of both uncommitted osteoblast progenitors and differentiated osteoblasts by beta-catenin-dependent and -independent signaling cascades involving Src/ERK and phosphatidylinositol 3-kinase/AKT. J. Biol. Chem. 2005, 280, 41342-41351. [CrossRef]

27. Qiang, Y.W.; Shaughnessy, J.D.; Yaccoby, S. Wnt3a signaling within bone inhibits multiple myeloma bone disease and tumor growth. Blood 2008, 112, 374-382. [CrossRef]

28. Delgado-Calle, J.; Anderson, J.; Cregor, M.D.; Condon, K.W.; Kuhstoss, S.A.; Plotkin, L.I.; Bellido, T.; Roodman, G.D. Genetic deletion of Sost or pharmacological inhibition of sclerostin prevent multiple myeloma-induced bone disease without affecting tumor growth. Leukemia 2017, 31, 2686-2694. [CrossRef]

29. Gavriatopoulou, M.; Dimopoulos, M.A.; Christoulas, D.; Migkou, M.; Iakovaki, M.; Gkotzamanidou, M.; Terpos, E. Dickkopf-1: A suitable target for the management of myeloma bone disease. Expert Opin. Ther. Targets 2009, 13, 839-848. [CrossRef]

30. Tian, E.; Zhan, F.; Walker, R.; Rasmussen, E.; Ma, Y.; Barlogie, B.; Shaughnessy, J.D. The role of the Wnt-signaling antagonist DKK1 in the development of osteolytic lesions in multiple myeloma. N. Engl. J. Med. 2003, 349, 2483-2494. [CrossRef]

31. Mao, B.; Wu, W.; Davidson, G.; Marhold, J.; Li, M.; Mechler, B.M.; Delius, H.; Hoppe, D.; Stannek, P.; Walter, C.; et al. Kremen proteins are Dickkopf receptors that regulate Wnt/beta-catenin signalling. Nature 2002, 417, 664-667. [CrossRef] [PubMed] 
32. Gunn, W.G.; Conley, A.; Deininger, L.; Olson, S.D.; Prockop, D.J.; Gregory, C.A. A crosstalk between myeloma cells and marrow stromal cells stimulates production of DKK1 and interleukin-6: A potential role in the development of lytic bone disease and tumor progression in multiple myeloma. Stem Cells 2006, 24, 986-991. [CrossRef] [PubMed]

33. Spencer, G.J.; Utting, J.C.; Etheridge, S.L.; Arnett, T.R.; Genever, P.G. Wnt signalling in osteoblasts regulates expression of the receptor activator of NFkappaB ligand and inhibits osteoclastogenesis in vitro. J. Cell Sci. 2006, 119, 1283-1296. [CrossRef]

34. Sutherland, M.K.; Geoghegan, J.C.; Yu, C.; Turcott, E.; Skonier, J.E.; Winkler, D.G.; Latham, J.A. Sclerostin promotes the apoptosis of human osteoblastic cells: A novel regulation of bone formation. Bone 2004, 35, 828-835. [CrossRef] [PubMed]

35. Winkler, D.G.; Sutherland, M.K.; Geoghegan, J.C.; Yu, C.; Hayes, T.; Skonier, J.E.; Shpektor, D.; Jonas, M.; Kovacevich, B.R.; Staehling-Hampton, K.; et al. Osteocyte control of bone formation via sclerostin, a novel BMP antagonist. EMBO J. 2003, 22, 6267-6276. [CrossRef] [PubMed]

36. Colucci, S.; Brunetti, G.; Oranger, A.; Mori, G.; Sardone, F.; Specchia, G.; Rinaldi, E.; Curci, P.; Liso, V.; Passeri, G.; et al. Myeloma cells suppress osteoblasts through sclerostin secretion. Blood Cancer J. 2011, 1, e27. [CrossRef]

37. Terpos, E.; Christoulas, D.; Katodritou, E.; Bratengeier, C.; Gkotzamanidou, M.; Michalis, E.; Delimpasi, S.; Pouli, A.; Meletis, J.; Kastritis, E.; et al. Elevated circulating sclerostin correlates with advanced disease features and abnormal bone remodeling in symptomatic myeloma: Reduction post-bortezomib monotherapy. Int. J. Cancer 2012, 131, 1466-1471. [CrossRef]

38. Shinohara, M.; Chang, B.Y.; Buggy, J.J.; Nagai, Y.; Kodama, T.; Asahara, H.; Takayanagi, H. The orally available Btk inhibitor ibrutinib (PCI-32765) protects against osteoclast-mediated bone loss. Bone 2014, 60, 8-15. [CrossRef]

39. Lee, S.H.; Kim, T.; Jeong, D.; Kim, N.; Choi, Y. The tec family tyrosine kinase Btk Regulates RANKL-induced osteoclast maturation. J. Biol. Chem. 2008, 283, 11526-11534. [CrossRef]

40. Edwards, C.M. BTK inhibition in myeloma: Targeting the seed and the soil. Blood 2012, 120, 1757-1759. [CrossRef]

41. Kania, M.A.; Bonner, A.S.; Duffy, J.B.; Gergen, J.P. The Drosophila segmentation gene runt encodes a novel nuclear regulatory protein that is also expressed in the developing nervous system. Genes Dev. 1990, 4, 1701-1713. [CrossRef] [PubMed]

42. Mori, K.; Kitazawa, R.; Kondo, T.; Maeda, S.; Yamaguchi, A.; Kitazawa, S. Modulation of mouse RANKL gene expression by Runx2 and PKA pathway. J. Cell Biochem. 2006, 98, 1629-1644. [CrossRef] [PubMed]

43. Trotter, T.N.; Li, M.; Pan, Q.; Peker, D.; Rowan, P.D.; Li, J.; Zhan, F.; Suva, L.J.; Javed, A.; Yang, Y. Myeloma cell-derived Runx2 promotes myeloma progression in bone. Blood 2015, 125, 3598-3608. [CrossRef] [PubMed]

44. Musolino, C.; Allegra, A.; Innao, V.; Allegra, A.G.; Pioggia, G.; Gangemi, S. Inflammatory and Anti-Inflammatory Equilibrium, Proliferative and Antiproliferative Balance: The Role of Cytokines in Multiple Myeloma. Mediat. Inflamm. 2017, 2017, 1852517. [CrossRef]

45. Botta, C.; Di Martino, M.T.; Ciliberto, D.; Cucè, M.; Correale, P.; Rossi, M.; Tagliaferri, P.; Tassone, P. A gene expression inflammatory signature specifically predicts multiple myeloma evolution and patients survival. Blood Cancer J. 2016, 6, e511. [CrossRef]

46. Harmer, D.; Falank, C.; Reagan, M.R. Interleukin-6 Interweaves the Bone Marrow Microenvironment, Bone Loss, and Multiple Myeloma. Front Endocrinol. (Lausanne) 2018, 9, 788. [CrossRef]

47. Pellegrino, A.; Ria, R.; Di Pietro, G.; Cirulli, T.; Surico, G.; Pennisi, A.; Morabito, F.; Ribatti, D.; Vacca, A. Bone marrow endothelial cells in multiple myeloma secrete CXC-chemokines that mediate interactions with plasma cells. Br. J. Haematol. 2005, 129, 248-256. [CrossRef]

48. Herrero, A.B.; García-Gómez, A.; Garayoa, M.; Corchete, L.A.; Hernández, J.M.; San Miguel, J.; Gutierrez, N.C. Effects of IL-8 Up-Regulation on Cell Survival and Osteoclastogenesis in Multiple Myeloma. Am. J. Pathol. 2016, 186, 2171-2182. [CrossRef]

49. Børset, M.; Sundan, A.; Waage, A.; Standal, T. Why do myeloma patients have bone disease? A historical perspective. Blood Rev. 2019, 100646. [CrossRef] 
50. Roussou, M.; Tasidou, A.; Dimopoulos, M.A.; Kastritis, E.; Migkou, M.; Christoulas, D.; Gavriatopoulou, M.; Zagouri, F.; Matsouka, C.; Anagnostou, D.; et al. Increased expression of macrophage inflammatory protein-1alpha on trephine biopsies correlates with extensive bone disease, increased angiogenesis and advanced stage in newly diagnosed patients with multiple myeloma. Leukemia 2009, 23, 2177-2181. [CrossRef]

51. Lam, J.; Takeshita, S.; Barker, J.E.; Kanagawa, O.; Ross, F.P.; Teitelbaum, S.L. TNF-alpha induces osteoclastogenesis by direct stimulation of macrophages exposed to permissive levels of RANK ligand. J. Clin. Investig. 2000, 106, 1481-1488. [CrossRef] [PubMed]

52. Hengeveld, P.J.; Kersten, M.J. B-cell activating factor in the pathophysiology of multiple myeloma: A target for therapy? Blood Cancer J. 2015, 5, e282. [CrossRef]

53. Vallet, S.; Mukherjee, S.; Vaghela, N.; Hideshima, T.; Fulciniti, M.; Pozzi, S.; Santo, L.; Cirstea, D.; Patel, K.; Sohani, A.R.; et al. Activin A promotes multiple myeloma-induced osteolysis and is a promising target for myeloma bone disease. Proc. Natl. Acad. Sci. USA 2010, 107, 5124-5129. [CrossRef] [PubMed]

54. Sugatani, T.; Alvarez, U.M.; Hruska, K.A. Activin A stimulates IkappaB-alpha/NFkappaB and RANK expression for osteoclast differentiation, but not AKT survival pathway in osteoclast precursors. J. Cell Biochem. 2003, 90, 59-67. [CrossRef] [PubMed]

55. Breen, E.C.; Ignotz, R.A.; McCabe, L.; Stein, J.L.; Stein, G.S.; Lian, J.B. TGF beta alters growth and differentiation related gene expression in proliferating osteoblasts in vitro, preventing development of the mature bone phenotype. J. Cell Physiol. 1994, 160, 323-335. [CrossRef]

56. Ruan, M.; Pederson, L.; Bradley, E.W.; Bamberger, A.M.; Oursler, M.J. Transforming growth factor-\{beta\} coordinately induces suppressor of cytokine signaling 3 and leukemia inhibitory factor to suppress osteoclast apoptosis. Endocrinology 2010, 151, 1713-1722. [CrossRef]

57. Gingery, A.; Bradley, E.W.; Pederson, L.; Ruan, M.; Horwood, N.J.; Oursler, M.J. TGF-beta coordinately activates TAK1/MEK/AKT/NFkB and SMAD pathways to promote osteoclast survival. Exp. Cell Res. 2008, 314, 2725-2738. [CrossRef]

58. Matsumoto, T.; Abe, M. TGF- $\beta$-related mechanisms of bone destruction in multiple myeloma. Bone 2011, 48, 129-134. [CrossRef]

59. Takeuchi, K.; Abe, M.; Hiasa, M.; Oda, A.; Amou, H.; Kido, S.; Harada, T.; Tanaka, O.; Miki, H.; Nakamura, S.; et al. Tgf-Beta inhibition restores terminal osteoblast differentiation to suppress myeloma growth. PLoS ONE 2010, 5, e9870. [CrossRef]

60. Paton-Hough, J.; Tazzyman, S.; Evans, H.; Lath, D.; Down, J.M.; Green, A.C.; Snowden, J.A.; Chantry, A.D.; Lawson, M.A. Preventing and Repairing Myeloma Bone Disease by Combining Conventional Antiresorptive Treatment With a Bone Anabolic Agent in Murine Models. J. Bone Miner. Res. 2019, 34, 783-796. [CrossRef]

61. Mercer, T.R.; Dinger, M.E.; Mattick, J.S. Long non-coding RNAs: Insights into functions. Nat. Rev. Genet. 2009, 10, 155-159. [CrossRef] [PubMed]

62. Amodio, N.; Raimondi, L.; Juli, G.; Stamato, M.A.; Caracciolo, D.; Tagliaferri, P.; Tassone, P. MALAT1: A druggable long non-coding RNA for targeted anti-cancer approaches. J. Hematol. Oncol. 2018, 11, 63. [CrossRef] [PubMed]

63. Bartel, D.P. MicroRNAs: Genomics, biogenesis, mechanism, and function. Cell 2004, 116, 281-297. [CrossRef]

64. Slack, F.J.; Chinnaiyan, A.M. The Role of Non-coding RNAs in Oncology. Cell 2019, 179, 1033-1055. [CrossRef] [PubMed]

65. Di Martino, M.T.; Gullà, A.; Gallo Cantafio, M.E.; Altomare, E.; Amodio, N.; Leone, E.; Morelli, E.; Lio, S.G.; Caracciolo, D.; Rossi, M.; et al. In vitro and in vivo activity of a novel locked nucleic acid (LNA)-inhibitor-miR-221 against multiple myeloma cells. PLoS ONE 2014, 9, e89659. [CrossRef] [PubMed]

66. Gullà, A.; Di Martino, M.T.; Gallo Cantafio, M.E.; Morelli, E.; Amodio, N.; Botta, C.; Pitari, M.R.; Lio, S.G.; Britti, D.; Stamato, M.A.; et al. A 13 mer LNA-i-miR-221 Inhibitor Restores Drug Sensitivity in Melphalan-Refractory Multiple Myeloma Cells. Clin. Cancer Res. 2016, 22, 1222-1233. [CrossRef]

67. Di Martino, M.T.; Gullà, A.; Cantafio, M.E.; Lionetti, M.; Leone, E.; Amodio, N.; Guzzi, P.H.; Foresta, U.; Conforti, F.; Cannataro, M.; et al. In vitro and in vivo anti-tumor activity of miR-221/222 inhibitors in multiple myeloma. Oncotarget 2013, 4, 242-255. [CrossRef]

68. Fan, F.Y.; Deng, R.; Lai, S.H.; Wen, Q.; Zeng, Y.; Gao, L.; Liu, Y.; Kong, P.; Zhong, J.; Su, Y.; et al. Inhibition of microRNA-221-5p induces osteogenic differentiation by directly targeting smad3 in myeloma bone disease mesenchymal stem cells. Oncol. Lett. 2019, 18, 6536-6544. [CrossRef] 
69. Eskildsen, T.; Taipaleenmäki, H.; Stenvang, J.; Abdallah, B.M.; Ditzel, N.; Nossent, A.Y.; Bak, M.; Kauppinen, S.; Kassem, M. MicroRNA-138 regulates osteogenic differentiation of human stromal (mesenchymal) stem cells in vivo. Proc. Natl. Acad. Sci. USA 2011, 108, 6139-6144. [CrossRef]

70. Tsukamoto, S.; Løvendorf, M.B.; Park, J.; Salem, K.Z.; Reagan, M.R.; Manier, S.; Zavidij, O.; Rahmat, M.; Huynh, D.; Takagi, S.; et al. Inhibition of microRNA-138 enhances bone formation in multiple myeloma bone marrow niche. Leukemia 2018, 32, 1739-1750. [CrossRef] [PubMed]

71. Fan, F.Y.; Deng, R.; Qiu, L.; Wen, Q.; Zeng, Y.; Gao, L.; Zhang, C.; Kong, P.; Zhong, J.; Zeng, N.; et al. miR-203a-3p.1 is involved in the regulation of osteogenic differentiation by directly targeting Smad9 in MM-MSCs. Oncol. Lett. 2019, 18, 6339-6346. [CrossRef] [PubMed]

72. Leone, E.; Morelli, E.; Di Martino, M.T.; Amodio, N.; Foresta, U.; Gullà, A.; Rossi, M.; Neri, A.; Giordano, A.; Munshi, N.C.; et al. Targeting miR-21 inhibits in vitro and in vivo multiple myeloma cell growth. Clin. Cancer Res. 2013, 19, 2096-2106. [CrossRef] [PubMed]

73. Löffler, D.; Brocke-Heidrich, K.; Pfeifer, G.; Stocsits, C.; Hackermüller, J.; Kretzschmar, A.K.; Burger, R.; Gramatzki, M.; Blumert, C.; Bauer, K.; et al. Interleukin-6 dependent survival of multiple myeloma cells involves the Stat3-mediated induction of microRNA-21 through a highly conserved enhancer. Blood 2007, 110, 1330-1333. [CrossRef] [PubMed]

74. Sugatani, T.; Vacher, J.; Hruska, K.A. A microRNA expression signature of osteoclastogenesis. Blood 2011, 117, 3648-3657. [CrossRef] [PubMed]

75. Wang, X.; Li, C.; Ju, S.; Wang, Y.; Wang, H.; Zhong, R. Myeloma cell adhesion to bone marrow stromal cells confers drug resistance by microRNA-21 up-regulation. Leuk. Lymphoma 2011, 52, 1991-1998. [CrossRef]

76. Pitari, M.R.; Rossi, M.; Amodio, N.; Botta, C.; Morelli, E.; Federico, C.; Gullà, A.; Caracciolo, D.; Di Martino, M.T.; Arbitrio, M.; et al. Inhibition of miR-21 restores RANKL/OPG ratio in multiple myeloma-derived bone marrow stromal cells and impairs the resorbing activity of mature osteoclasts. Oncotarget 2015, 6, 27343-27358. [CrossRef]

77. Rossi, M.; Altomare, E.; Botta, C.; Gallo Cantafio, M.E.; Sarvide, S.; Caracciolo, D.; Riillo, C.; Gaspari, M.; Taverna, D.; Conforti, F.; et al. miR-21 antagonism abrogates Th17 tumor promoting functions in multiple myeloma. Leukemia 2020. [CrossRef]

78. Amodio, N.; Rossi, M.; Raimondi, L.; Pitari, M.R.; Botta, C.; Tagliaferri, P.; Tassone, P. miR-29s: A family of epi-miRNAs with therapeutic implications in hematologic malignancies. Oncotarget 2015, 6, 12837-12861. [CrossRef]

79. Stamato, M.A.; Juli, G.; Romeo, E.; Ronchetti, D.; Arbitrio, M.; Caracciolo, D.; Neri, A.; Tagliaferri, P.; Tassone, P.; Amodio, N. Inhibition of EZH2 triggers the tumor suppressive miR-29b network in multiple myeloma. Oncotarget 2017, 8, 106527-106537. [CrossRef]

80. Amodio, N.; Bellizzi, D.; Leotta, M.; Raimondi, L.; Biamonte, L.; D'Aquila, P.; Di Martino, M.T.; Calimeri, T.; Rossi, M.; Lionetti, M.; et al. miR-29b induces SOCS-1 expression by promoter demethylation and negatively regulates migration of multiple myeloma and endothelial cells. Cell Cycle 2013, 12, 3650-3662. [CrossRef]

81. Amodio, N.; Leotta, M.; Bellizzi, D.; Di Martino, M.T.; D'Aquila, P.; Lionetti, M.; Fabiani, F.; Leone, E.; Gullà, A.M.; Passarino, G.; et al. DNA-demethylating and anti-tumor activity of synthetic miR-29b mimics in multiple myeloma. Oncotarget 2012, 3, 1246-1258. [CrossRef] [PubMed]

82. Amodio, N.; Stamato, M.A.; Gullà, A.M.; Morelli, E.; Romeo, E.; Raimondi, L.; Pitari, M.R.; Ferrandino, I.; Misso, G.; Caraglia, M.; et al. Therapeutic Targeting of miR-29b/HDAC4 Epigenetic Loop in Multiple Myeloma. Mol. Cancer Ther. 2016, 15, 1364-1375. [CrossRef] [PubMed]

83. Li, Z.; Hassan, M.Q.; Jafferji, M.; Aqeilan, R.I.; Garzon, R.; Croce, C.M.; van Wijnen, A.J.; Stein, J.L.; Stein, G.S.; Lian, J.B. Biological functions of miR-29b contribute to positive regulation of osteoblast differentiation. J. Biol. Chem. 2009, 284, 15676-15684. [CrossRef] [PubMed]

84. Rossi, M.; Pitari, M.R.; Amodio, N.; Di Martino, M.T.; Conforti, F.; Leone, E.; Botta, C.; Paolino, F.M.; Del Giudice, T.; Iuliano, E.; et al. miR-29b negatively regulates human osteoclastic cell differentiation and function: Implications for the treatment of multiple myeloma-related bone disease. J. Cell Physiol. 2013, 228, 1506-1515. [CrossRef]

85. Botta, C.; Cucè, M.; Pitari, M.R.; Caracciolo, D.; Gullà, A.; Morelli, E.; Riillo, C.; Biamonte, L.; Gallo Cantafio, M.E.; Prabhala, R.; et al. MiR-29b antagonizes the pro-inflammatory tumor-promoting activity of multiple myeloma-educated dendritic cells. Leukemia 2018, 32, 1003-1015. [CrossRef] 
86. Misiewicz-Krzeminska, I.; Sarasquete, M.E.; Quwaider, D.; Krzeminski, P.; Ticona, F.V.; Paíno, T.; Delgado, M.; Aires, A.; Ocio, E.M.; García-Sanz, R.; et al. Restoration of microRNA-214 expression reduces growth of myeloma cells through positive regulation of P53 and inhibition of DNA replication. Haematologica 2013, 98, 640-648. [CrossRef]

87. Hao, M.; Zang, M.; Zhao, L.; Deng, S.; Xu, Y.; Qi, F.; An, G.; Qin, Y.; Sui, W.; Li, F.; et al. Serum high expression of miR-214 and miR-135b as novel predictor for myeloma bone disease development and prognosis. Oncotarget 2016, 7, 19589-19600. [CrossRef]

88. Xu, S.; Cecilia Santini, G.; De Veirman, K.; Vande Broek, I.; Leleu, X.; De Becker, A.; Van Camp, B.; Vanderkerken, K.; Van Riet, I. Upregulation of miR-135b is involved in the impaired osteogenic differentiation of mesenchymal stem cells derived from multiple myeloma patients. PLoS ONE 2013, 8, e79752. [CrossRef]

89. Gowda, P.S.; Wildman, B.J.; Trotter, T.N.; Xu, X.; Hao, X.; Hassan, M.Q.; Yang, Y. Runx2 Suppression by miR-342 and miR-363 Inhibits Multiple Myeloma Progression. Mol. Cancer Res. 2018, 16, 1138-1148. [CrossRef]

90. Xu, X.; Zhang, C.; Trotter, T.N.; Gowda, P.S.; Lu, Y.; Ponnazhagan, S.; Javed, A.; Li, J.; Yang, Y. Runx2 Deficiency in Osteoblasts Promotes Myeloma Progression by Altering the Bone Microenvironment at New Bone Sites. Cancer Res. 2020, 80, 1036-1048. [CrossRef]

91. Sugatani, T.; Hruska, K.A. MicroRNA-223 is a key factor in osteoclast differentiation. J. Cell Biochem. 2007, 101, 996-999. [CrossRef] [PubMed]

92. Haneklaus, M.; Gerlic, M.; O’Neill, L.A.; Masters, S.L. miR-223: Infection, inflammation and cancer. J. Intern. Med. 2013, 274, 215-226. [CrossRef] [PubMed]

93. Berenstein, R.; Nogai, A.; Waechter, M.; Blau, O.; Kuehnel, A.; Schmidt-Hieber, M.; Kunitz, A.; Pezzutto, A.; Dörken, B.; Blau, I.W. Multiple myeloma cells modify VEGF/IL-6 levels and osteogenic potential of bone marrow stromal cells via Notch/miR-223. Mol. Carcinog. 2016, 55, 1927-1939. [CrossRef] [PubMed]

94. Kopp, F.; Mendell, J.T. Functional Classification and Experimental Dissection of Long Noncoding RNAs. Cell 2018, 172, 393-407. [CrossRef] [PubMed]

95. Ma, L.; Bajic, V.B.; Zhang, Z. On the classification of long non-coding RNAs. RNA Biol. 2013, 10, 925-933. [CrossRef]

96. Wang, K.C.; Chang, H.Y. Molecular mechanisms of long noncoding RNAs. Mol. Cell 2011, 43, 904-914. [CrossRef]

97. Zhu, J.; Chen, S.; Yang, B.; Mao, W.; Yang, X.; Cai, J. Molecular mechanisms of lncRNAs in regulating cancer cell radiosensitivity. Biosci. Rep. 2019, 39. [CrossRef]

98. Shi, T.; Gao, G.; Cao, Y. Long Noncoding RNAs as Novel Biomarkers Have a Promising Future in Cancer Diagnostics. Dis. Markers 2016, 2016, 9085195. [CrossRef]

99. Arriaga-Canon, C.; De La Rosa-Velázquez, I.A.; González-Barrios, R.; Montiel-Manríquez, R.; Oliva-Rico, D.; Jiménez-Trejo, F.; Cortés-González, C.; Herrera, L.A. The use of long non-coding RNAs as prognostic biomarkers and therapeutic targets in prostate cancer. Oncotarget 2018, 9, 20872-20890. [CrossRef]

100. Kelemen, E.; Danis, J.; Göblös, A.; Bata-Csörgő, Z.; Széll, M. Exosomal long non-coding RNAs as biomarkers in human diseases. EJIFCC 2019, 30, 224-236.

101. Li, G.; Shi, H.; Wang, X.; Wang, B.; Qu, Q.; Geng, H.; Sun, H. Identification of diagnostic long non-coding RNA biomarkers in patients with hepatocellular carcinoma. Mol. Med. Rep. 2019, 20, 1121-1130. [CrossRef] [PubMed]

102. Huarte, M. The emerging role of lncRNAs in cancer. Nat. Med. 2015, 21, 1253-1261. [CrossRef] [PubMed]

103. Du, Z.; Fei, T.; Verhaak, R.G.; Su, Z.; Zhang, Y.; Brown, M.; Chen, Y.; Liu, X.S. Integrative genomic analyses reveal clinically relevant long noncoding RNAs in human cancer. Nat. Struct. Mol. Biol. 2013, 20, 908-913. [CrossRef] [PubMed]

104. Butova, R.; Vychytilova-Faltejskova, P.; Souckova, A.; Sevcikova, S.; Hajek, R. Long Non-Coding RNAs in Multiple Myeloma. Noncoding RNA 2019, 5, 13. [CrossRef] [PubMed]

105. Misiewicz-Krzeminska, I.; Krzeminski, P.; Corchete, L.A.; Quwaider, D.; Rojas, E.A.; Herrero, A.B.; Gutiérrez, N.C. Factors Regulating microRNA Expression and Function in Multiple Myeloma. Noncoding RNA 2019, 5, 9. [CrossRef]

106. Ronchetti, D.; Agnelli, L.; Taiana, E.; Galletti, S.; Manzoni, M.; Todoerti, K.; Musto, P.; Strozzi, F.; Neri, A. Distinct lncRNA transcriptional fingerprints characterize progressive stages of multiple myeloma. Oncotarget 2016, 7, 14814-14830. [CrossRef] 
107. Ronchetti, D.; Agnelli, L.; Pietrelli, A.; Todoerti, K.; Manzoni, M.; Taiana, E.; Neri, A. A compendium of long non-coding RNAs transcriptional fingerprint in multiple myeloma. Sci. Rep. 2018, 8, 6557. [CrossRef]

108. Samur, M.K.; Minvielle, S.; Gulla, A.; Fulciniti, M.; Cleynen, A.; Aktas Samur, A.; Szalat, R.; Shammas, M.; Magrangeas, F.; Tai, Y.T.; et al. Long intergenic non-coding RNAs have an independent impact on survival in multiple myeloma. Leukemia 2018, 32, 2626-2635. [CrossRef]

109. Allegra, A.; Mania, M.; D'Ascola, A.; Oteri, G.; Siniscalchi, E.N.; Avenoso, A.; Innao, V.; Scuruchi, M.; Allegra, A.G.; Musolino, C.; et al. Altered Long Noncoding RNA Expression Profile in Multiple Myeloma Patients with Bisphosphonate-Induced Osteonecrosis of the Jaw. BioMed Res. Int. 2020, 2020, 9879876. [CrossRef]

110. Li, B.; Han, H.; Song, S.; Fan, G.; Xu, H.; Zhou, W.; Qiu, Y.; Qian, C.; Wang, Y.; Yuan, Z.; et al. HOXC10 Regulates Osteogenesis of Mesenchymal Stromal Cells Through Interaction with Its Natural Antisense Transcript lncHOXC-AS3. Stem Cells 2019, 37, 247-256. [CrossRef]

111. Cai, H.; Xue, Y.; Wang, P.; Wang, Z.; Li, Z.; Hu, Y.; Shang, X.; Liu, Y. The long noncoding RNA TUG1 regulates blood-tumor barrier permeability by targeting miR-144. Oncotarget 2015, 6, 19759-19779. [CrossRef] [PubMed]

112. Xu, Y.; Leng, K.; Li, Z.; Zhang, F.; Zhong, X.; Kang, P.; Jiang, X.; Cui, Y. The prognostic potential and carcinogenesis of long non-coding RNA TUG1 in human cholangiocarcinoma. Oncotarget 2017, 8, 65823-65835. [CrossRef] [PubMed]

113. Li, Z.; Shen, J.; Chan, M.T.; Wu, W.K. TUG1: A pivotal oncogenic long non-coding RNA of human cancers. Cell Prolif. 2016, 49, 471-475. [CrossRef] [PubMed]

114. Yin, Q.; Shen, X.; Cui, X.; Ju, S. Elevated serum lncRNA TUG1 levels are a potential diagnostic biomarker of multiple myeloma. Exp. Hematol. 2019, 79, 47-55.e42. [CrossRef]

115. Ji, Q.; Cai, G.; Liu, X.; Zhang, Y.; Wang, Y.; Zhou, L.; Sui, H.; Li, Q. MALAT1 regulates the transcriptional and translational levels of proto-oncogene RUNX2 in colorectal cancer metastasis. Cell Death Dis. 2019, 10, 378. [CrossRef]

116. Arun, G.; Aggarwal, D.; Spector, D.L. Long Non-Coding RNA: Functional Implications. Noncoding RNA 2020, 6, 22. [CrossRef]

117. Castro-Oropeza, R.; Melendez-Zajgla, J.; Maldonado, V.; Vazquez-Santillan, K. The emerging role of lncRNAs in the regulation of cancer stem cells. Cell Oncol. (Dordr) 2018, 41, 585-603. [CrossRef]

118. Cho, S.F.; Chang, Y.C.; Chang, C.S.; Lin, S.F.; Liu, Y.C.; Hsiao, H.H.; Chang, J.G.; Liu, T.C. MALAT1 long non-coding RNA is overexpressed in multiple myeloma and may serve as a marker to predict disease progression. BMC Cancer 2014, 14, 809. [CrossRef]

119. Amodio, N.; Stamato, M.A.; Juli, G.; Morelli, E.; Fulciniti, M.; Manzoni, M.; Taiana, E.; Agnelli, L.; Cantafio, M.E.G.; Romeo, E.; et al. Drugging the lncRNA MALAT1 via LNA gapmeR ASO inhibits gene expression of proteasome subunits and triggers anti-multiple myeloma activity. Leukemia 2018, 32, 1948-1957. [CrossRef]

120. Xiao, X.; Zhou, T.; Guo, S.; Guo, C.; Zhang, Q.; Dong, N.; Wang, Y. LncRNA MALAT1 sponges miR-204 to promote osteoblast differentiation of human aortic valve interstitial cells through up-regulating Smad4. Int. J. Cardiol. 2017, 243, 404-412. [CrossRef]

121. Zhuang, W.; Ge, X.; Yang, S.; Huang, M.; Chen, P.; Zhang, X.; Fu, J.; Qu, J.; Li, B. Upregulation of lncRNA MEG3 Promotes Osteogenic Differentiation of Mesenchymal Stem Cells From Multiple Myeloma Patients By Targeting BMP4 Transcription. Stem Cells 2015, 33, 1985-1997. [CrossRef] [PubMed]

122. Li, Z.; Jin, C.; Chen, S.; Zheng, Y.; Huang, Y.; Jia, L.; Ge, W.; Zhou, Y. Long non-coding RNA MEG3 inhibits adipogenesis and promotes osteogenesis of human adipose-derived mesenchymal stem cells via miR-140-5p. Mol. Cell Biochem. 2017, 433, 51-60. [CrossRef] [PubMed]

123. Zhang, Y.; Zhang, X.O.; Chen, T.; Xiang, J.F.; Yin, Q.F.; Xing, Y.H.; Zhu, S.; Yang, L.; Chen, L.L. Circular intronic long noncoding RNAs. Mol. Cell 2013, 51, 792-806. [CrossRef] [PubMed]

124. Preußer, C.; Hung, L.H.; Schneider, T.; Schreiner, S.; Hardt, M.; Moebus, A.; Santoso, S.; Bindereif, A. Selective release of circRNAs in platelet-derived extracellular vesicles. J. Extracell Vesicles 2018, 7, 1424473. [CrossRef] [PubMed]

125. Pamudurti, N.R.; Bartok, O.; Jens, M.; Ashwal-Fluss, R.; Stottmeister, C.; Ruhe, L.; Hanan, M.; Wyler, E.; Perez-Hernandez, D.; Ramberger, E.; et al. Translation of CircRNAs. Mol. Cell 2017, 66, 9-21.e27. [CrossRef] [PubMed] 
126. Vicens, Q.; Westhof, E. Biogenesis of Circular RNAs. Cell 2014, 159, 13-14. [CrossRef]

127. Dahl, M.; Daugaard, I.; Andersen, M.S.; Hansen, T.B.; Grønbæk, K.; Kjems, J.; Kristensen, L.S. Enzyme-free digital counting of endogenous circular RNA molecules in B-cell malignancies. Lab. Investig. 2018, 98, 1657-1669. [CrossRef]

128. Wang, F.; Nazarali, A.J.; Ji, S. Circular RNAs as potential biomarkers for cancer diagnosis and therapy. Am. J. Cancer Res. 2016, 6, 1167-1176.

129. Kristensen, L.S.; Hansen, T.B.; Venø, M.T.; Kjems, J. Circular RNAs in cancer: Opportunities and challenges in the field. Oncogene 2018, 37, 555-565. [CrossRef]

130. Dahl, M.; Kristensen, L.S.; Grønbæk, K. Long Non-Coding RNAs Guide the Fine-Tuning of Gene Regulation in B-Cell Development and Malignancy. Int. J. Mol. Sci. 2018, 19, 2475. [CrossRef]

131. Feng, Y.; Zhang, L.; Wu, J.; Khadka, B.; Fang, Z.; Gu, J.; Tang, B.; Xiao, R.; Pan, G.; Liu, J. CircRNA circ_0000190 inhibits the progression of multiple myeloma through modulating miR-767-5p/MAPK4 pathway. J. Exp. Clin. Cancer Res. 2019, 38, 54. [CrossRef] [PubMed]

132. Liu, X.; Tang, H.; Liu, J.; Wang, X. hsa_circRNA_101237: A Novel Diagnostic and Prognostic Biomarker and Potential Therapeutic Target for Multiple Myeloma. Cancer Manag. Res. 2020, 12, 2109-2118. [CrossRef] [PubMed]

133. Gao, M.; Li, C.; Xiao, H.; Dong, H.; Jiang, S.; Fu, Y.; Gong, L. hsa_circ_0007841: A Novel Potential Biomarker and Drug Resistance for Multiple Myeloma. Front. Oncol. 2019, 9, 1261. [CrossRef] [PubMed]

134. Van Niel, G.; D'Angelo, G.; Raposo, G. Shedding light on the cell biology of extracellular vesicles. Nat. Rev. Mol. Cell Biol. 2018, 19, 213-228. [CrossRef]

135. Mathieu, M.; Martin-Jaular, L.; Lavieu, G.; Théry, C. Specificities of secretion and uptake of exosomes and other extracellular vesicles for cell-to-cell communication. Nat. Cell Biol. 2019, 21, 9-17. [CrossRef]

136. Johnstone, R.M.; Adam, M.; Hammond, J.R.; Orr, L.; Turbide, C. Vesicle formation during reticulocyte maturation. Association of plasma membrane activities with released vesicles (exosomes). J. Biol. Chem. 1987, 262, 9412-9420.

137. Li, B.; Hong, J.; Hong, M.; Wang, Y.; Yu, T.; Zang, S.; Wu, Q. piRNA-823 delivered by multiple myeloma-derived extracellular vesicles promoted tumorigenesis through re-educating endothelial cells in the tumor environment. Oncogene 2019, 38, 5227-5238. [CrossRef]

138. Di Noto, G.; Chiarini, M.; Paolini, L.; Mazzoldi, E.L.; Giustini, V.; Radeghieri, A.; Caimi, L.; Ricotta, D. Immunoglobulin Free Light Chains and GAGs Mediate Multiple Myeloma Extracellular Vesicles Uptake and Secondary NfkB Nuclear Translocation. Front. Immunol. 2014, 5, 517. [CrossRef]

139. Liu, Y.; Zhu, X.J.; Zeng, C.; Wu, P.H.; Wang, H.X.; Chen, Z.C.; Li, Q.B. Microvesicles secreted from human multiple myeloma cells promote angiogenesis. Acta Pharmacol. Sin. 2014, 35, 230-238. [CrossRef]

140. Cheng, Q.; Li, X.; Liu, J.; Ye, Q.; Chen, Y.; Tan, S. Multiple Myeloma-Derived Exosomes Regulate the Functions of Mesenchymal Stem Cells Partially via Modulating miR-21 and miR-146a. Stem Cells Int. 2017, 2017, 9012152. [CrossRef]

141. De Veirman, K.; Wang, J.; Xu, S.; Leleu, X.; Himpe, E.; Maes, K.; De Bruyne, E.; Van Valckenborgh, E.; Vanderkerken, K.; Menu, E.; et al. Induction of miR-146a by multiple myeloma cells in mesenchymal stromal cells stimulates their pro-tumoral activity. Cancer Lett. 2016, 377, 17-24. [CrossRef] [PubMed]

142. Raimondo, S.; Urzì, O.; Conigliaro, A.; Raimondi, L.; Amodio, N.; Alessandro, R. Emerging Insights on the Biological Impact of Extracellular Vesicle-Associated ncRNAs in Multiple Myeloma. Noncoding RNA 2020, 6, 30. [CrossRef]

143. Wang, J.; Hendrix, A.; Hernot, S.; Lemaire, M.; De Bruyne, E.; Van Valckenborgh, E.; Lahoutte, T.; De Wever, O.; Vanderkerken, K.; Menu, E. Bone marrow stromal cell-derived exosomes as communicators in drug resistance in multiple myeloma cells. Blood 2014, 124, 555-566. [CrossRef] [PubMed]

144. Faict, S.; Oudaert, I.; D’Auria, L.; Dehairs, J.; Maes, K.; Vlummens, P.; De Veirman, K.; De Bruyne, E.; Fostier, K.; Vande Broek, I.; et al. The Transfer of Sphingomyelinase Contributes to Drug Resistance in Multiple Myeloma. Cancers 2019, 11, 1823. [CrossRef]

145. Raimondi, L.; De Luca, A.; Amodio, N.; Manno, M.; Raccosta, S.; Taverna, S.; Bellavia, D.; Naselli, F.; Fontana, S.; Schillaci, O.; et al. Involvement of multiple myeloma cell-derived exosomes in osteoclast differentiation. Oncotarget 2015, 6, 13772-13789. [CrossRef] 
146. Raimondo, S.; Saieva, L.; Vicario, E.; Pucci, M.; Toscani, D.; Manno, M.; Raccosta, S.; Giuliani, N.; Alessandro, R. Multiple myeloma-derived exosomes are enriched of amphiregulin (AREG) and activate the epidermal growth factor pathway in the bone microenvironment leading to osteoclastogenesis. J. Hematol. Oncol. 2019, 12, 2. [CrossRef]

147. Li, B.; Xu, H.; Han, H.; Song, S.; Zhang, X.; Ouyang, L.; Qian, C.; Hong, Y.; Qiu, Y.; Zhou, W.; et al. Exosome-mediated transfer of lncRUNX2-AS1 from multiple myeloma cells to MSCs contributes to osteogenesis. Oncogene 2018, 37, 5508-5519. [CrossRef]

148. Zhang, L.; Lei, Q.; Wang, H.; Xu, C.; Liu, T.; Kong, F.; Yang, C.; Yan, G.; Sun, L.; Zhao, A.; et al. Tumor-derived extracellular vesicles inhibit osteogenesis and exacerbate myeloma bone disease. Theranostics 2019, 9, 196-209. [CrossRef]

149. Raimondo, S.; Urzì, O.; Conigliaro, A.; Bosco, G.L.; Parisi, S.; Carlisi, M.; Siragusa, S.; Raimondi, L.; Luca, A.; Giavaresi, G.; et al. Extracellular Vesicle microRNAs Contribute to the Osteogenic Inhibition of Mesenchymal Stem Cells in Multiple Myeloma. Cancers 2020, 12, 449. [CrossRef]

150. Liu, Z.; Liu, H.; Li, Y.; Shao, Q.; Chen, J.; Song, J.; Fu, R. Multiple myeloma-derived exosomes inhibit osteoblastic differentiation and improve IL-6 secretion of BMSCs from multiple myeloma. J. Investig. Med. 2020, 68, 45-51. [CrossRef]

151. Strømme, O.; Psonka-Antonczyk, K.M.; Stokke, B.T.; Sundan, A.; Arum, C.J.; Brede, G. Myeloma-derived extracellular vesicles mediate HGF/c-Met signaling in osteoblast-like cells. Exp. Cell Res. 2019, 383, 111490. [CrossRef] [PubMed]

152. Faict, S.; Muller, J.; De Veirman, K.; De Bruyne, E.; Maes, K.; Vrancken, L.; Heusschen, R.; De Raeve, H.; Schots, R.; Vanderkerken, K.; et al. Exosomes play a role in multiple myeloma bone disease and tumor development by targeting osteoclasts and osteoblasts. Blood Cancer J. 2018, 8, 105. [CrossRef] [PubMed]

153. Nolte-'t Hoen, E.N.; Buermans, H.P.; Waasdorp, M.; Stoorvogel, W.; Wauben, M.H.; 't Hoen, P.A. Deep sequencing of RNA from immune cell-derived vesicles uncovers the selective incorporation of small non-coding RNA biotypes with potential regulatory functions. Nucleic Acids Res. 2012, 40, 9272-9285. [CrossRef]

154. Valadi, H.; Ekström, K.; Bossios, A.; Sjöstrand, M.; Lee, J.J.; Lötvall, J.O. Exosome-mediated transfer of mRNAs and microRNAs is a novel mechanism of genetic exchange between cells. Nat. Cell Biol. 2007, 9, 654-659. [CrossRef]

155. Nabet, B.Y.; Qiu, Y.; Shabason, J.E.; Wu, T.J.; Yoon, T.; Kim, B.C.; Benci, J.L.; DeMichele, A.M.; Tchou, J.; Marcotrigiano, J.; et al. Exosome RNA Unshielding Couples Stromal Activation to Pattern Recognition Receptor Signaling in Cancer. Cell 2017, 170, 352-366.e313. [CrossRef]

156. Santangelo, L.; Giurato, G.; Cicchini, C.; Montaldo, C.; Mancone, C.; Tarallo, R.; Battistelli, C.; Alonzi, T.; Weisz, A.; Tripodi, M. The RNA-Binding Protein SYNCRIP Is a Component of the Hepatocyte Exosomal Machinery Controlling MicroRNA Sorting. Cell Rep. 2016, 17, 799-808. [CrossRef] 